\title{
The Moral Menace of Roman Law and the Making of Commerce: Some Dutch Evidence
}

\author{
James Q. Whitman ${ }^{\dagger}$
}

Did Roman law represent a kind of moral menace in premodern Europe, encouraging commercialism, greed, and exploitativeness, and fostering a lifeless "rationalism"? In one version or another, this idea has been accepted by Europeans for centuries. Petrarch was already warning his readers in the Middle Ages that the practice of Roman law was a nursery of corrupt and mercenary values; ${ }^{1}$ and in the early-modern period many Europeans took the same view. ${ }^{2}$ Even in modern times, some of our greatest legal historians have put their authority behind the idea that Roman law was somehow morally menacing. The most famous scholarly version of the idea came from Heinrich Brunner, who, around the turn of the century, described the spread of Roman law through medieval and early-modern Europe as the spread of "destructive

$\dagger$ Professor of Law, Yale University. I gratefully acknowledge the comments of participants in workshops at Harvard Law School, Boalt Hall, and Yale Law School. Among individuals, I would particularly like to acknowledge generous suggestions from Hans Ankum, Mary Ann Case, Mirjan Damaska, Charles Donahue, David Gerber, James Gordley, Morton Horwitz, Duncan Kennedy, Peter Landau, John Langbein, Andrea McDowell, Walter Pakter, Carol Rose, Frank Sander, Alan Schwartz, Peter Stein, Detlev Vagts, Jeremy Waldron, Stephen Walt, and Reinhard Zimmermann. All translations, unless otherwise noted, are my own.

1. See, e.g., PETRARCh, Epistle to Posterity (1351), in LETTERS FROM PETRARCh 5, 8 (Morris Bishop trans., 1966); see also James Q. Whitman, The Lawyers Discover the Fall of Rome, 9 LAW \& HIST. REV. 191, 191-92, 207-10 (1991).

2. The history of hostility to Roman law is most familiar as a history of German hostility to Roman law. On anti-Roman sentiment in Germany, see the careful assessment in PETER BENDER, DIE REZEPTION DES RÖMISCHEN RECHTS IM URTEIL DER DEUTSCHEN RECHTSWISSENSCHAFT 28-53 (1979), which traces the development of anti-Roman sentiment through the seventeenth and eighteenth centuries. Less reliable, in my view, is GERALD STRAuSS, LAW, RESISTANCE, AND THE STATE: THE OPPOSITION TO ROMAN LAW IN REFORMATION GERMANY (1986), which exaggerates the extent to which sixteenth-century Germans opposed Roman law rather than learned law. See Alfred Stern, Das römische Recht und der deutsche Bauemkrieg, 14 ZEITSCHRIFT FŬR SCHWEIZERISCHE GESCHICHTE 20 (1934); JAMES Q. WHITMAN, THE LEGACY OF ROMAN LAW IN THE GERMAN ROMANTIC ERA 20 n.67 (1990). Despite the greater familiarity with the German history of anti-Roman-law sentiment, however, the more important and thoughtful tradition of hostility arguably developed, in the early-modern period, among the less-studied French lawyers. For useful discussion, see DONALD R. KELlEY, FOUNDATIONS OF MODERN Historical Scholarship 271-300 (1970); PAUL OURLIAC \& JEAN-LouIS GAZZANIGA, HISTOIRE DU DROIT PRIVÉ FRANÇAIS DE L'AN MIL AU CODE CIVIL 157-68 (1985). A typical example of the greater awareness of the German than of the French history is MANLIo Bellomo, THE COMMON LEGAL PAST OF EuRope, 1000-1800, at 206-08, 217-20 (Lydia G. Cochrane trans., 1995). 
infections." But Brunner was not the only major scholar to mount this sort of claim. Max Weber, to choose the most important example, also ascribed destructive impact to the spread of "rationalistic" Roman law, though his tone was of course more sober than Brunner's; ${ }^{4}$ and the same idea left its mark on the writings of Karl Marx ${ }^{5}$ and Ferdinand Tönnies, ${ }^{6}$ among others. ${ }^{7}$ The idea has had a life in modern politics too. Through Marx, Engels, and Proudhon, it established itself in the general lexicon of socialist thought on the rise of capitalist society. ${ }^{8}$ Not least, it made its way into the ideological underworld of the German far right wing: Point 19 of the Nazi party program denounced Roman law as a vector of the "materialistic world-order" and demanded its elimination. ${ }^{9}$

But venerable though this idea may be, it has largely dropped from sight since 1945, at least among professional legal historians. Most specialists today, I think it is fair to say, simply laugh, or grimace, at the idea that Roman law held some kind of moral menace for traditional values; and standard textbooks confidently reject any connection between Roman law and the rise of modern commerce. ${ }^{10}$ The idea is particularly out of favor in Germany, where it has so many ugly associations with Nazi ideology." But even legal historians who know little about the Nazi experience, I would guess, typically find the whole notion of studying the commercializing impact of Roman law to be pretty much passé. Certainly, legal historians see no sense in discussing the unsavory idea that Roman law had some kind of damaging effect on European morals.

Nevertheless, in this Article, I want to discuss this old idea seriously. I think it is time that we wrestle again with the venerable question of the link between Roman law and the morals of the "materialistic world-order."

3. HEINRICH BRUNNER, GRUNDZÜGE DER DEUTSCHEN RECHTSGESCHICHTE 265 (7th ed. 1921); Heinrich Brunner, Quellen und Geschichte des deutschen Rechts, in 1 ENZYKLOPÄDIE DER RECHTSWISSENSCHAFT 65 (Josef Kohler ed., 1904); see also James Q. Whitman, The Disease Idea of Roman Law: A Century Later, Lecture Delivered to the 1993 Meeting of the American Society of Comparative Law, inaccurately transcribed in The Disease of Roman Law: A Century Later, 20 SYRACUSE J. INT'L L. \& COM. 227 (1994).

4. See Whitman, supra note 3, at 231.

5. See infra note 17

6. See infra note 23 and accompanying text.

7. See, e.g., RUDOLF STAMMLER, WIRTSCHAFT UND RECHT NACH DER MATERIALISTISCHEN GESCHICHTSAUFFASSUNG 305 (4th ed. 1921).

8. See, e.g., W.A. TUMANOW, BÜRGERLICHE RECHTSIDEOLOGIE 33 (1975); infra text accompanying notes 17-18.

9. See Peter Landau, Römisches Recht und deutsches Gemeinrecht. Zur rechtspolitischen Zielsetzung im nationalsozialistischen Parteiprogramm, in RECHTSGESCHICHTE IM NATIONALSOZIALISMUS 11, 20-21 (Michael Stolleis \& Dieter Simon eds., 1989).

10. See infra text accompanying notes $27-36$.

11. See, as far back as 1930, the novel of LION FeUCHTVANGER, ERFOLG 120, 556 (1995) (1930), for passages satirizing Nazi denunciations of Roman law. For the classic postwar statement, see PAUL KOSCHAKER, EUROPA UND DAS RÖMISCHE RECHT 311-15 (4th ed. 1966) (1947). The association of this topic with the Nazis, and the discomfort of German scholars in dealing with Nazi topics, are sensitively sketched in MICHAEL STOLLEIS, RECHT IM UNRECHT: STUDIEN ZUR RECHTSGESCHICHTE DES NATIONALSOZIALISMUS 57-93 (1994). 
Unsavory as this old idea may sometimes sound, there are (as the work of some medievalists has recently suggested ${ }^{12}$ ) important arguments to be made for the claim that Roman law laid some of the behavioral foundation for the rise of commercial society. And those arguments are not only important for our understanding of European legal history. This is an issue that goes to the heart of the rise of modern commerce. As I am going to try to show, discussing the question of the "morally corrupting" impact of Roman law, at first glance so bizarre, will help us approach a deeper question about the development of a commercial order: the question of the extent to which the legal history of commerce is a history, not just of the rise of functioning commercial institutions, but also of the rise of a commercial morality. More broadly, discussing the "morally corrupting" impact of Roman law will help us see the importance of a question that hovers over all legal historiography: the question of whether we can really disentangle the history of law from the history of ideas of good and evil, right and wrong.

I am going to begin by reviewing what the great legal historians of the nineteenth century said on this topic, sketching out some classic claims about how the spread of Roman law brought moral evil in its wake. I will concentrate on two charges against Roman law in particular: first, the charge that Roman law's "property absolutism" made it peculiarly "unbrotherly" or "uncommunal"; and second, the charge that Roman law was excessively "rationalistic." Both of these nineteenth-century charges had notable impact on the formation of classical sociology, and I will describe, if only briefly, how they worked their way into the theories of Tönnies and Weber. Both of these claims also had notable impact on the making of Nazi legal ideology. Both of them, as I will discuss, are generally dismissed, or simply ignored, by legal historians today.

After laying these classic charges out, I will turn to some new sources, in an effort to show that the classic idea that the spread of Roman law had a specifically moral impact is still worth investigating, even if the classic accounts of that impact are by no means clearly correct. I am not going to

12. See John W. Baldwin, The Medieval Theories of the Just Price: Romanists, Canonists, and Theologians in the Twelfth and Thirteenth Centuries, TRANSACTIONS AM. PHIL. SOC'Y, July 1959, at 1 (discussing important question of just-price theory). The literature on this topic has grown steadily. See the sources cited and discussed in HERBERT KALB, LAESIO ENORMIS IM GELEHRTEN RECHT: KANONISTISCHE STUdIEN ZUR LÄSIONSANFECHTUNG 105-219 (Kirche und Recht No. 19, 1992) and JACOB VINER, RELIGIOUS THOUGHT AND ECONOMIC SOCIETY: FouR CHAPTERS OF AN UNFINISHED WORK (Jacques Melitz \& Donald Winch eds., 1978). This medieval tradition has not failed to attract the attention of American legal scholars, and is explored with great learning and insight in David J. Gerber, Prometheus Born: The High Middle Ages and the Relationship between Law and Economic Conduct, 38 ST. LouIS U. L.J. 673 (1994), and JAMES GORDLEY, THE PHILOSOPHICAL ORIGINS OF MODERN CONTRACT DOCTRINE (1991). This Article offers, in many ways, a continuation of the work to be found in these writings. For American readers, the history of medieval just-price theory will be most familiar from the brief discussion in A.W.B. Simpson, The Honvitz Thesis and the History of Contracts, 46 U. CHI. L. REV. 533, 536-38 (1979). The strictures of Professor Gordley, and my own, with regard to Simpson's well-known argument, are presented below. See infra text accompanying notes $68-70$. 
claim that the spread of Roman law "caused" the rise of commercial society, as some nineteenth-century scholars used to do. But I will argue that we can detect important links between the moral lessons of Roman law and the rise of commercial society.

In particular, I am going to argue that we can detect important links between Roman law and the rise of a kind of commercial morality at the scene of a major leap forward in the development of modern commerce: the seventeenth-century Netherlands (which I will generally call, using the ordinary shorthand, "Holland"). ${ }^{13}$ Holland has been strangely neglected in our literature. When legal historians discuss the problem of the connection between Roman law and the rise of commercial society, they almost invariably look to the cases of early-modern England or of the cities of the Hanseatic league; and they typically argue that since England and the Hansa had no Roman law, no connection between Roman law and the rise of commercial society can plausibly be drawn. As for the medievalists: They inevitably focus on the Middle Ages, believing that the growth of medieval trade can be equated with the rise of a modern commercial society. Yet, by the common consensus of historians, it was in seventeenth-century Holland, not in England or in the Hansa or in medieval Italy, that the most striking and seminal developments in the rise of a modern commercial order took place; and it is clear that we must turn much of our attention to Holland in discussing this question.

In discussing the rise of Dutch commercial society, I am going to focus on areas of law different from those that occupied the attention of nineteenth-century scholars. Nineteenth-century scholars largely concentrated on property law and on patterns of legal reasoning, attributing the evils of Roman law to its supposed "property absolutism" and its supposed "rationalism." By contrast, I am going to focus on more narrowly commercial topics: sales and bankruptcy law. I am also going to exploit a different sort of source than nineteenth-century historians typically used-vernacular guides to law and morality produced by practitioners and preachers in the early seventeenth century.

By the end of the Article, I will conclude that Roman law did indeed contribute something to the progress of what the nineteenth century called "unbrotherly" and "uncommunal" commercial values in seventeenth-century Holland. In particular, I will try to show that Roman law was linked to revolutionary changes in two critical areas of Dutch commercial law, neither of which has been understood by historians of commercial law: first, the Dutch abandonment of longstanding just-price principles; and second, the Dutch abandonment of traditional shame sanctions inflicted upon bankrupts. (With

13. Holland was, as is well known, only one of several "United Provinces," though the dominant one by far. Readers should be aware not only that there were a number of provinces, but that the legal traditions of those provinces varied to some degree. There are nevertheless good reasons for speaking, as historians commonly do, of a general Dutch commercial law. See infra note 37. 
regard to just price in particular, I will try to show that the great Dutch commercial revolution was marked by an important, and neglected, evolution: a transition from the regulation of price to the regulation of quality.) In the areas both of just price and of bankruptcy, Roman law encouraged critical changes in commercial morality; and if we understand these little-understood points, I will argue, we will see that the spread of Roman law was indeed a large factor in the rise of a very new kind of commercial society.

In short, Roman law was connected with important changes in moral perceptions, just as Petrarch, Brunner, Weber, and so many others (among them, sadly, the Nazis) claimed; the history of law is connected with the history of morals. But that does not mean that the grand old prewar tradition of Marx, Weber, Tönnies, and the rest-what I will call the classic tradition-was wholly correct; just as it certainly does not mean that the Nazis were correct. The classic tradition, I will conclude, fell prey to two important errors of interpretation. First of all, the classic tradition made a significant nationalistic error, interpreting European legal history as a conflict between Roman and Germanic law, when in fact the great conflict was much more one between Roman and Christian law. Second, and more broadly, the classic tradition ultimately overstated the moral impact of Roman law. Pre-1945 authors, whether on the right wing or the left, liked to speak as though the spread of Roman texts had altered the very behavioral structure of European societies - as though the mere availability of Roman law had, ipso facto, induced Europeans to conduct themselves and perceive the world differently, causing them to be more "unbrotherly," or more "acquisitive," or more "rational." But we must recognize that the impact of Roman law was more modest than that. The appearance of Roman law in a society did not, as such, induce anyone to behave differently. What was important about the spread of Roman law, I will argue, was simply that it made available one set of normative justifications for commercial behavior-behavior whose ultimate social-psychological sources must, however, be sought outside the confines of the law itself. Roman law did not cause the rise of a new commercial morality in seventeenth-century Holland; it helped justify the rise of a new commercial morality-and therein lies a distinction, I will conclude, with some important implications.

Let us begin with some basic facts. After the collapse of the western Roman Empire, the serious study of Roman law came to an end in what is now western Europe. Only around the year 1100 A.D. did scholars in northern Italy begin, in mysterious circumstances, to work through the obscure, 
complex, and very alien texts of Roman law. ${ }^{14}$ In subsequent centuries, both the study and the practical use of Roman law spread, though at different rates and in very different ways, into all parts of transalpine Europe; and by the later sixteenth century, Roman law was in heavy use all through the Continent. ${ }^{15}$

From the beginning of this rediscovery and spread of Roman law, there were jurists who found Roman law to be a suspect and dangerous body of authority; and the belief that Roman law carried some kind of threat to traditional values came to be frequently voiced in the long history of European law. In the premodern world, this belief always appeared in vague and inarticulate form. But when the discipline of modern legal history began in the nineteenth century, scholars tried to put this old belief on a more careful, "scientific" footing.

These "scientific" arguments of the nineteenth century took two principal forms: ${ }^{16}$ first, the argument that Roman law had had evil consequences because its "property absolutism" made it peculiarly "uncommunal"; and second, that Roman law had had evil consequences because it was excessively "rationalistic." Both of these arguments had a great influence on the making of nineteenth-century social thought, and both were eagerly touted during the Nazi period. Both, it is worth emphasizing, were principally value-laden arguments, arguments that sought to show that there was something bad about the spread of Roman law-either that Roman law had brought with it socioeconomic evil, or else that the use of Roman law had damaged Europeans' moral sense, their sense of right and wrong in their treatment of others. These nineteenth-century arguments were thus different from the sorts of value-neutral arguments that we generally make today when we try to account for the rise of modern commerce. For most of our arguments are, of course, carefully framed as nonpolemical arguments about legal technique, about the building of smoothly functioning commercial institutions.

The first of the great nineteenth-century claims about the moral impact of Roman law was the claim that Roman "property absolutism" led to the decay of "communal" or "brotherly" values and so gave rise to a baleful commercialism. This claim took a number of forms in the nineteenth century, all of which were based on an undoubted, if slippery, truth in the history of European law: Roman law tended to assign "ownership" rights to some single "owner," both in the case of real property and in the case of personalty. Feudal law, by contrast, tended to speak not of "ownership," but of "investiture": Early-medieval holders of property, whether real or personal, were typically

14. See Stephan Kuttner, The Revival of Jurisprudence, in RENAISSANCE AND RENEWAL IN THE TWELFTH CENTURY 229, 229-323 (Robert Benson \& Giles Constable eds., 1982).

15. See the various volumes of the series IUS ROMANUM MEDIl AEVI (1961-).

16. These were, it should be said, only the principal forms. Also particularly important, though widely rejected, was the contention that the spread of Roman law contributed to the rise of princely power in Europe. On this argument, see HERMANN KRAUSE, KAISERRECHT UND REZEPTION (1952). 
"invested" with limited rights in that property, subject to a variety of duties of trust and good faith. The spread of Roman law was accordingly the spread of a new kind of "property absolutist" analysis, an analysis that sought to assign "ownership" rights exclusively to one person.

Many nineteenth-century scholars believed that the spread of this "property absolutism" lay at the heart of what was evil about the spread of Roman law. They interpreted the conflict between "property absolutism" and "property nonabsolutism" in a nationalistic way, as a conflict between Roman and "Germanic" national spirits; and they mounted a number of claims about how the spread of Roman "property absolutism" had been socially destructive. Some of those nineteenth-century claims are still familiar today. In particular, we all know what could be called the classic socialist argument: that the spread of Roman property absolutism inevitably meant the concentration of social resources in the hands of a limited class of "owners." This argument was pioneered by $\mathrm{Marx}{ }^{17}$ and Proudhon, ${ }^{18}$ and it is still widely accepted in the lay literature, particularly among historians of the French Revolution. ${ }^{19}$

But nineteenth-century scholars also developed other, less-familiar arguments about the consequences of Roman "property absolutism"arguments that focused not on the socioeconomic impact of changes in property law, but on the moral impact, on the impact of changes in property law upon the prevailing sense of one's moral duties to others. Beginning in $1828,{ }^{20}$ legal historians began to argue that the spread of Roman law had resulted, not merely in a redistribution of resources, but in changes in fundamental attitudes about trust and social duty. As one leading 1853 book put it, Roman and "Germanic" property law were informed by fundamentally different "basic intuitions [Grundanschauungen] about rights, freedom, and honor," and the tale of the spread of Roman law was the tale of how Roman intuitions had penetrated Germanic "legal consciousness."21 Scholars who worked along these lines generally argued that because Roman property rights

17. Marx's development can be traced from Karl Marx, Debates on the Law of Thefts of Wood, reprinted in 1 KARL MARX \& FREDERICK ENGELS, COLLECTED WORKS 233, 233 (Jack Cohen et al. eds., 1975) [hereinafter MARX \& ENGEls, ColleCtEd WoRkS], through KARL MARX \& FREDERICK ENGELS, THE GERMAN IDEOLOGY (1846), reprinted in 5 MARX \& ENGELS, COLLECTED WORKS, supra, at 89, 89-92, to later works in which Marx abandoned his references to Roman law while maintaining the analysis he had developed in discussing Roman law, see, e.g., KARL MARX, A CONTRIBUTION TO THE CRITIQUE OF POLITICAL ECONOMY (1859), reprinted in 29 MARX \& ENGELS, COLLECTED WORKS, supra, at 461, 461-64. For Engels on this question and his influence on later communist literature, see TUMANOW, supra note 8 , at 33 .

18. See Pierre-Joseph Proudhon, What is Property? 24-25, 35, passim (Donald R. Kelley \& Bonnie G. Smith eds. \& trans., 1994) (1890).

19. Most recently, Gerd van den Heuvel, Féodalité, Féodal, in 10 HaNDBUCH PoliTISCH-SOzIALER GRUNDBEGRIFFE IN FRANKREICH 1680-1820, at 4, 4-10 (Rolf Reichardt \& Eberhard Schnmitt eds., 1988).

20. $C f$. WILHELM E. AlbreCht, DiE GEWERE ALS GRUNDLAGE DES ÄLtERN DEUTSCHEN SACHENRECHTS (Königsberg, Gebruder Bomtrager 1828) (discussing supposed peculiar values of Germanic law).

21. CARL AdOLF SCHMidT, DeR PRINCIPIELle UNTERSCHIED ZWISCHEN DEM RöMISCHEN UND GERMANISCHEN RECHT 1-2, 13, 15 (Rostock, Stiller 1853). 
were not limited by obligations of trust or duty, the spread of Roman law encouraged an exploitative, antisocial, and "unbrotherly" attitude toward the world. The most famous technical version of this claim came from Otto von Gierke, who maintained that the psychic basis of Roman property law lay in the exercise of unfettered "will," whereas the psychic basis of Germanic law lay in the "morally bound will." Because Germanic law approached the social world in this "morally bound" way, Germanic law was "communal" where Roman law was "individualistic" and capitalistic.22 The same line of argument also had a formative influence on some of the classic thinkers of early sociology-in particular on Ferdinand Tönnies, who built a powerful theoretical apparatus around the idea that commercial "society" was founded on a different form of "will," and different attitudes toward property, from those of precommercial "community":

Acquisition [in "society"] is based on mere occupation, therefore, to the extent that others lose out, a robber-like activity.... [The merchant] stands isolated from all necessary relations (necessitudines), duties, prejudices, as much as possible (A merchant, it has been said very properly, is not necessarily the citizen of any particular country: Ad. Smith Wealth of Nations bk. III, ch. 4 ....). He is free from the bonds of communal life, and the more so the better for him. ${ }^{23}$

Merchants had a deep psychic kinship with pirates; and commercial society was the instantiation of the spirit of "acquisition." It was this idea, of the morally unhinging consequences of uncommunal Roman "property absolutism," that made the heaviest impact on the legal philosophy of the Nazi movement. From a very early date, Nazi tradition worked to fuse the socioeconomic arguments of the socialist tradition with the social-psychological arguments of Gierke and Tönnies. ${ }^{24}$

Alongside these claims about destructive Roman "property absolutism" arose the claim that Roman law carried with it a destructive "rationalism." This was another very old claim, which the early nineteenth century recast in terms redolent of a Romantic aversion to Enlightenment Reason. The claim of Roman "rationalism" was, we should note, a claim that could form either the basis of a value-neutral argument about the technical superiority of "rational" institutions or the basis of a value-laden argument about the evils of

22. Otto Gierke, Community in Historical Perspective 114-15, 242-43 (Antony Black ed. \& Mary Fischer trans., Cambridge Univ. Press 1990) (1868); OTTO GIERKE, DER ENTWURF DES BÜRGERLICHEN GESETZBUCHES UND DAS DEUTSCHE RECHT 3-4 (Leipzig, Duncker \& Humblot 1889).

23. FERdinAND TÖNNIES, GEMEINSCHAFT UND GESELLSCHAFT. GRUNDBEGRIFFE DER REINEN SOZIOLOGIE 57-58 (photo. reprint 1963) (Leipzig, Fues's Verlag 1887). For a full translation of the passage, see FERdiNAND TÖNNIES, COMMUNITY AND SOCIETY 80-81 (C. Loomis ed. \& trans., 1957). For Tönnies on will, see generally id. at 103-70.

24. See Landau, supra note 9, at 11-24; see also STOLLEIS, supra note 11, at 94, 114; Landau, supra note 9, at 20-23 (for vulgarization and irrationalization of Gierke). 
"rationalization." Very commonly, it served the second of these purposes, invoked by scholars who thought that rationalization was an evil, and in particular that Roman-law "rationalism" made lawyers lose touch with the healthy intuitions of lay folk. This very old idea had an obvious, but in some ways still little-explored, influence on Max Weber, who doubted that law could abandon its "rationalism" but who also saw the spread of "rationalism" as a sad thing. ${ }^{25}$ Through Weber and Heinrich Brunner, the old idea of Roman legal "rationalism" had a formative influence on our concept of the course of European legal history; for we still attribute the spread of Roman law, in one way or another, to its "rationalism." This was an idea, finally, that again flourished in the Nazi period; for Nazi jurisprudence was deeply shaped, as a number of recent scholarly works have shown, by hostility to excessive "rationalism" in law. ${ }^{26}$

Indeed, the Nazis made both the idea of Roman "property absolutism" and the idea of Roman "rationalism" much their own. Accordingly, it is not surprising that our technical literature rejects both of these claims and, more generally, the very idea of the commercializing impact of Roman law.

Indeed, the whole line of nineteenth-century scholarship I have described has largely died in our literature. In particular, when the topic of Roman law and commercial society comes up, modern textbooks commonly begin by denying that Roman law ever displayed true "property absolutism." The ancient world, our textbooks are thus eager to observe, never displayed full-scale property absolutism; nor indeed did the Roman law of the earlymodern world display full-scale property absolutism, for it is easy to demonstrate that no European has ever actually had unfettered "ownership."27 Ancient practice, moreover, never lacked either concepts of "good faith" or of trust, both of which were safeguarded both procedurally and substantively, and in ways that showed a clear awareness of the needs of commerce. ${ }^{28}$ Furthermore, our textbooks typically continue, even if Roman law did display property absolutism and lack of good faith, those characteristics hardly serve the ends of commerce. Property absolutism and lack of good faith, whatever their moral objectionability, are ill-suited to the techniques of commerce. Commerce is about rapid and smooth exchange. What is needed for commerce is, accordingly, not an absolutist conception of property, but easy transfer of

25. See the discussion in Whitman, supra note 3 , at 231 .

26. BERND RÜTHERS, DIE UNBEGRENZTE AUSLEGUNG (3d ed. 1988); see also OlIVER LEPSIUS, DIE GEGENSATZAUFHEBENDE BEGRIFFSBILDUNG. METHODENENTWICKLUNGEN IN DER WEIMARER REPUBLIK UND IHR VERHÄLTNIS ZUR IDEOLOGISIERUNG DER RECHTSWISSENSCHAFT UNTER DEM NATIONALSOZIALISMUS (1994).

27. See HEINRICH HONSELl ET AL., RÖMISCHES RECHT 142-43 (4th ed. 1987); Karl Kroeschell, Zur Lehre vom "germanischen Eigentumsbegriff," in RECHTSHISTORISCHE STUDIEN: FESTSCHRIFT FUR HANS THIEME ZUM 70. GEBURTSTAG ZUGEIGNET VON SEINEN SCHULERN 34, 34-37 (1977).

28. Here I condense a complex argument. See, e.g., FRANZ WIEACKER, RÖMISCHE RECHTSGESCHICHTE: QUELLENKUNDE, RECHTSBILDUNG, JURISPRUDENZ UND RECHTSLITERATUR 475-77 (1988). 
secure title, with far-reaching protection for good-faith claims. Yet an absolutist conception of property necessarily entails highly formal transfer of title, and a formalistic hostility to concepts of good faith. "Property absolutism" may sound ominously mercenary; but in point of fact, if consistently observed, it should tend to gum up the smooth movements of exchange. ${ }^{29}$ Following such reasoning, most of the standard textbooks today (particularly German-language ones) conclude that Roman law could scarcely, as a matter of legal technique, have provided the basis for the rise of commercial society; on the contrary, Germanic law, they argue, provided the predominant technical basis for the modern commercial tradition.

As for the idea of Roman "rationalism," it has largely vanished, at least in its full-blown value-laden form, from our textbooks. We still see it, to be sure, in one of the oldest textbooks in Germany, H. Mitteis and H. Lieberich's Deutsche Rechtsgeschichte, whose most recent edition repeats, in passing, a version of the sort of denunciatory claim that used to be made in the earlier part of this century:

The principal consequence of the spread of Roman law into Germany lies ... not in the transformation of German law into something alien as a result of the adoption of particular provisions, but rather in the transformation of the whole intellectual and cultural basis of the law. The alien legal system brought with it an entirely new method of thinking, and a new legal logic, which were incomprehensible to the People. In consequence, a deep rift opened between the People and the Law, between the People and the Legal Profession. At the same time, there was a sharpening of social antitheses: Only the rich could afford a trained advocate ....30

But the Mitteis/Lieberich textbook is something of an exception in maintaining any sense of the socially or morally evil impact of the spread of Roman-law "rationalism." Most legal historians, though they work in the Weberian tradition, do not choose to remember that Weber saw any dark side to the spread of legal order and science. The Weberian account, as it dominates in European legal history now, is overwhelmingly a sober institutionalsociological account of how the spread of Roman law followed the rise to prominence of professionally trained jurists. (Such is the version of European legal history we find, for example, in the important treatment of Franz Wieacker. ${ }^{31}$ ) The argument from Roman-law "rationalism," while it is still to

29. Here again I summarize a complex argument that revolves particularly around the law of commercial paper. For a classic discussion, see LEVIN GOLDSCHMIDT, UNiVERSALGESCHICHTE DES HANDELSRECHTS, 1 HANDBUCH DES HANDELSRECHTS 133-37 (Stuttgart, F. Enke 3d ed. 1891). 1988).

30. See HeinRich Mitteis \& Heinz Lieberich, Deutsche REChTSGeschichte 330-31 (18th ed.

31. Franz WieACKer, PRIVATREChtSgeschichte DER NEuZeit (2d ed. 1967). 
be heard, has become exclusively a value-neutral argument about legal technique.

The idea of Roman "property absolutism" is thus dead in the professional literature, and the idea of Roman "rationalism" lives on only in the most sanitized technical form. At the same time, scholars have widely accepted an important argument de facto: the argument that Roman law can be shown to have had no connection in fact with the rise of commercial society. As legal historians (unlike general historians of Europe $^{32}$ ) generally hold, ${ }^{33}$ commercial society arose in England ${ }^{34}$-or, as some Germans would have it, among the cities of the Hanseatic league. ${ }^{35}$ Yet neither England nor the Hansa used Roman law. ${ }^{36}$ How, then, could Roman law be associated with the rise of commercial society? This argument, widely heard, is probably, more than any other, today considered adequate to defeat any claim that Roman law in any sense brought with it commercialization. It is an argument particularly common among students and critics of Weber, for whom the case of the arguably "irrational" common law carries particular spice. But there are other versions too.

To the extent legal historians bother themselves at all about the question, it can fairly be said that the centuries-old European belief in the commercializing character of Roman law is simply dead.

Nevertheless, I now want to discuss seriously the venerable belief in the morally menacing character of Roman law. I think we have been too quick to abandon this old question. Of course, much of the characteristic scholarship of the nineteenth-century tradition was perverse and foolish; of course, many of the standard criticisms are very powerful. Of course, above all, it is misguided to write polemical history of the kind produced in the nineteenth century: We lose much more than we gain if we expend our energies on lamenting the rise of commercial society.

But if the scholars of the prewar world were wrong to surrender themselves to lamentation, that does not mean that they were wrong to believe

32. See infra text accompanying notes $40-43$.

33. Though the special importance of Holland is seen by Reinhard Zimmermann, Der Kaufvertrag, in DAS RÖMISCH-HOLLÄNDISCHE RECHT 145, 146 (R. Feenstra \& R. Zimmermann eds., 1992).

34. For this widespread assumption, see, for example, MICHAEL E. TIGAR \& MADELEINE R. LEVY, LAW AND THE RISE OF CAPITALISM 257-58 (1977); and, more searchingly, ANTHONY T. KRONMAN, MAX WEBER 120-24 (1983); David M. Trubek, Max Weber on Law and the Rise of Capitalism, 1972 WIS. L. REV. 720, 746-48.

35. Most recently, Karl Kroeschell, Die Rezeption der gelehrten Rechte und ihre Bedeutung für die Bildung des Territorialstaates, in I DEUTSCHE VERWALTUNGSGESCHICHTE 279, 281 (Kurt G.A. Jeserich et al. eds., 1983), with citations to further literature. 1982).

36. E.g., GERHARD KÖBLER, RECHTSGESCHICHTE: EIN SYSTEMATISCHER GRUNDRIB 149-50 (3d ed. 
that the rise of modern commerce can be somehow associated with changes in moral outlook. It may be foolish to write value-laden history; but that does not, after all, mean that it is foolish to write the history of morals. In fact, there is a good case to be made that by bringing their values to the sources, the scholars of the classic tradition were able to perceive truths about the moral drama of those sources that escape our vision today. Even their claims about Roman "property absolutism" perhaps expressed a truth about changing premodern moral perceptions-though I leave that question for discussion elsewhere. Nor perhaps were their claims of Roman "rationalism" wholly wrong.

But it was in particular when they spoke, as they sometimes did, of Roman legal "unbrotherliness," that they spoke of something that really does have a basis in the sources, and that belongs in our professional literature.

In trying to show that the old tradition of denunciation of Roman law had at least a grain of truth, I am going to focus on seventeenth-century Holland. ${ }^{37}$ For, of course, it was in Holland, not in England, that modern commercial society took its greatest leap forward. This fact, which is almost too well known to require documentation, has been strangely neglected by legal historians (even as critics of Weber's Protestant Ethic have focused intense attention upon Holland). ${ }^{38}$ Yet it was early-seventeenth-century Holland that was the home, it is generally agreed, of the first recognizably commercial society-denounced and admired as such by contemporaries (such as Sir Walter Raleigh ${ }^{39}$ ), and now vividly described for a wide readership by

37. In using the term "Holland," I ignore the existence of provincial differences in legal tradition which could not comfortably be ignored in a more detailed study. But I believe my approach here is justified for two reasons: first, the sheer dominance of the law of Holland within the provinces in commercial matters, see WILHELM F. LICHTENAUER, GESCHIEDENIS VAN DE WETENSCHAP VAN HET HANDELRECHT IN NEDERLAND TOT 1809, at 12 (1956) [hereinafter LICHTENAUER, GESCHIEDENIS], and the tendency throughout the provinces to draw on the same sources, see id. at 81-154 (survey of sources); and second, and more importantly, my methodological approach here, which is to look at the sources that merchants, overwhelmingly active in Holland, would have considered in deciding on their courses of action. For the variety of the provinces, and the justification for the general practice of focusing on Holland, see Reinhard Zimmermann, Roman-Dutch Jurisprudence and its Contribution to European Private Law, 66 TUL. L. REV. 1685, 1687-88 n.10 (1992).

38. There has been, of course, much literature on the details of Dutch law, of which I have made grateful use. Most recently, a great deal of learned literature, on a variety of questions, is surveyed in DAS RÖMISCH-HOLLÄNDISCHE RECHT, supra note 33. Indispensable are the following contributions to HANDBUCH DER QUELLEN UND LITERATUR DER NEUEREN EUROPÄISCHEN RECHTSGESCHICHTE (Helmut Coing ed., 1973) [hereinafter CoING, HANDBUCH]: Christoph Bergfeld, Katholische Moraltheologie und Naturrechtslehre, in 2, pt. 1 COING, HANDBUCH, supra, at 999; Siegbert Lammel, Die Gesetzgebung des Handelsrechts, in 2, pt. 12 CoING, HANDBUCH, supra, at 744; Karl O. Schemer, Die Wissenschaft des Handelsrechts, in 2, pt. 1 COING, HANDBUCH, supra, at 797. Of the older literature, still important are JOSEF KOHLER, Niederländisches Handelsrecht in der Blütezeit des Freistaates, in ZEITSCHRIFT FÜR DAS GESAMTE HANDELSRECHT UND KONKURSRECHT 59 (1907), and LICHTENAUER, GESCHIEDENIS, supra note 37. It can fairly be said, however, that none of this literature approaches the large questions I discuss here, with the exception of Kohler's work, which, however, remains bound up in nationalist assumptions of the kind whose fallaciousness I try here to demonstrate. See infra note 162.

39. SIR WALTER RALEIGH, Observations touching Trade and Comerce with the Hollander, and Other Nations: Presented to King James, in 8 WoRks 351, 351-76 (London, R. Dodsley 1751). 
Simon Schama. ${ }^{40}$ It was in Amsterdam, not London, that the world's first thriving capital markets appeared, as well as the world's first state bank (and the world's first shopping guide). ${ }^{41}$ It was in Holland that large commercial companies were financed through the broad public sale of capital shares. It was Dutch society that displayed the flourishing markets widely deplored in Europe as focuses of a misguided commercial morality. It was Dutch merchants who stirred fear and hatred among the English and Spanish contemporaries whom they outcompeted, despite their relatively small numbers, building a worldwide commercial dominance of a kind that had never been seen. Obviously, the history of European commerce must begin in the Middle Ages, as Robert Lopez famously demonstrated..$^{42}$ But equally obviously, a critical social transformation took place in seventeenth-century Holland, and any tale we tell must be one in which Holland plays a peculiarly large role. ${ }^{43}$

And when we look to Holland, in the throes of its spectacular commercialization, we can see that Roman law had a significant, if hardly determinative, impact. We do not, to be sure, find a body of fully functioning Roman commercial law in the Dutch sources. We do not find "rationalism" of the Weberian or Brunnerian kind. We do not find property absolutism of the kind that Marx or Tönnies described. But we do find some striking things: As I will show in a separate paper, we find that Roman law was actually used in Dutch commercial transactions. The frequently repeated claim that only "Germanic" legal technique could serve as the basis of commercial practice is thus, at least in large part, demonstrably false.

Most importantly, we find Roman law used, in the Dutch sources, as justificatory moral authority for important aspects of commercial behavior that were condemned as "unbrotherly" by Christian tradition.

To show this, I am going to focus on a kind of literature that has not attracted much attention from legal historians: vernacular guides to morality and law, written for lay folk. Most legal historians who have treated Holland have trained their sights on the sophisticated law of learned Dutch scholars, who produced an extraordinarily subtle body of legal scholarship known as "Roman-Dutch law." ${ }^{44}$ That subtle body of scholarship is not my subject here. I am going to look away from the world of sophisticated legal scholarship,

40. SiMON SCHAMA, THE EMBARRASSMENT OF RICHES (1987); $c f$. JONATHAN I. ISRAEL, THE DUTCH REPUBLIC: ITS RISE, GREATNESS, AND FALL, 1477-1806 (1995) (describing contemporary reactions to Dutch society). "The United Provinces . . . were widely perceived in Europe as a seedbed of theological, intellectual, and social promiscuity which subverted the usual, and proper, relations between men and women, Christians and non-Christians, masters and servants, nobles and non-nobles, soldiers and civilians ...." Id. at 2.

41. See generally SchamA, supra note 40 , at $345-46$ (discussing Wisselbank); id. at $300-04$ (describing Fokken's shopping guide).

42. See Robert S. LOPEZ, THE COMMERCIAL REVOlution OF tHE Middle AGES, 9S0-1350 (1971).

43. For this point, see most recently JonATHAN I. ISRAEL, DUTCH PRIMACY IN WORLD TRADE, $1585-1740$, at 4 (1989).

44. See especially now a work by the immensely learned Reinhard Zimmermann, supra note 37. 
focusing instead on the worlds of everyday practice and of everyday moral concerns as revealed in the Dutch-language literature that was bought and owned by lay Dutch merchants. My hope, in exploiting this popular literature, is to gain a new and different kind of insight into the cultural impact of Roman law.

Within the vernacular literature that I will exploit, I will focus upon two particular examples: the law of just price in sales, which was centrally important to the organization of premodern markets, and the law of bankruptcy. With regard to both of these topics, we will see Roman law declaring permissible commercial behavior that was violently denounced by the Christian tradition. With regard to both topics, we will see Roman law in revealingly increased use in seventeenth-century Holland. These are important, and badly neglected, points, I will argue-though they are points whose importance we can grasp only if we let drop some of the methodological assumptions of the classic German tradition. For the best way to understand these facts is, as it were, neither Marxian nor Weberian but Nietzschean. What Roman law told Dutch merchants, as they broke free from centuries of Christian restrictions, was that many things are allowed. If we recognize that fact, and if we abandon some of the sociology we have inherited, directly from Weber and Tönnies, and indirectly from figures such as Gierke and Brunner, we will be able to return, with fresh eyes, to the classic problems of the field.

\section{III}

Roman law mattered in the everyday life of Holland, first and foremost, I want to argue, because it performed a task that is entirely unnecessary today: It offered justifications for varieties of market behavior that Christian Europeans had long viewed as sinister and wrong. This means that, in order for us to grasp what Roman law meant in the commercial life of the earlymodern Dutch world, we must make an effort to grasp how sinister marketplace relations used to seem. In particular, it is essential that we recover some sense of how morally uncertain the life of a merchant was believed to be. For before the modern commercial revolution could take place, it was necessary for Europeans to overcome a critical behavioral barrier: the Christian belief that engaging in commerce endangered the immortal soul.

We can capture some of the issues at stake by reading one particularly engrossing genre of early-seventeenth-century Dutch literature: moral-advice books, produced by Calvinist authors as spiritual guides for laypersons. This is a species of literature that has been eagerly exploited by critics of Weber's Protestant Ethic thesis, who have argued that the worldview of Dutch Calvinist moralists did not significantly differ from the worldview of the Catholic 
moralists of other parts of Europe. ${ }^{45} \mathrm{I}$ am going to try to show that these critics are wrong; the Dutch moral-advice literature does indeed differ from the Christian literature of the rest of Europe. But if the critics of Weber are wrong in their conclusions, they are right to choose the moral-advice literature as their source, for it offers a remarkable window into the inner moral life of commercializing Holland.

We may take, for example, the preacher Godfried Udemans's Spiritual Rudder of the Merchant's Ship ${ }^{46}$ published in 1638 as a "True Account of how a Merchant or Ship's Master must comport himself in his affairs, in Peace and in War, before God and Man, at Sea and on Land, especially among the Heathens in the East and West Indies." ${ }^{37}$ Udemans's book, written for an age in which merchants were indeed difficult to distinguish from pirates, ${ }^{48}$ continued to repeat Christian objections to profit-seeking behavior that had long intimidated European audiences, and it gives us a lively sense of the degree to which market behavior could seem profoundly dangerous to Dutch merchants caught up in the great commercial revolution.

Udemans's book, written in Dutch and published in portable octavo format, was aimed at a broad merchant audience. In particular, it was clearly aimed to give that audience a solid moral shock, informing them of frightening Christian principles that had traditionally been communicated to merchants by their confessors. The book is prefaced by a dedicatory letter, addressed to the directors of the East and West India Companies, and full of disturbing words. Some of the ancient teachers, Udemans told his readers, repeating matter that had long been common coin in confessors' manuals of the Middle Ages, had said frightening things:

such as what is observed by Saint Chrysostomus, who comments, in his Homilies, on the text of Matth. 21, 12: And Jesus went into the temple, etc. "Herewith," says Chrysostomus, "is given to understand that a merchant is hardly ever, or never, pleasing to God, and accordingly, no Christian should become a merchant; if he does so,

45. See Ernst Beins, Die Wirtschafisethik der Calvinistischen Kirche der Niederlande 1565-1650, in 24 NEDERLANDSCH ARCHIEF VOOR KERKGESCHIEDENIS (n.s.) 81, 81-156 (1931) (exploring moralizing literature in order to test validity of Weber hypothesis).

46. GODFRIED UDEMANS, 'T GEESTELYCK ROER VAN 'T COOPMANS SCHIP, DAT IS: TROW BERICHT' HOE DAT EEN COOPMAN, EN COOPVAERDER, HEMSELVEN DRAGEN MOET IN SYNE HANDELINGE/ IN PAYS, END IN OORLOGHE, VOOR GODT, ENDE DE MENSCHEN, TE WATER ENDE TE LANDE, INSONDERHEYT ONDER HEYDENEN IN OOST ENDE WEST-INDIEN: TER EEREN GODTS, STICHTINGE SYNER GHEMEYNTEN, ENDE SALICHEYT SYNER ZIELEN: MIDTSGADERS TOT HET TIJDTLIJCK WELVAREN VAN HET VADERLANDT, ENDE SYNE FAMIILIE (Dordrecht, Fransoys Boels 1638).

47. Westerman too linked merchants and warriors. See ADAM WESTERMAN, GROOTE CHRISTELIJCKE ZEE-VAERT in XXVI. PREDICATIEN (Amsterdam, By Gerrit van Goedesbergh 1653), which was addressed both to the merchant and to Oorloghs-Volck, persons involved in war. For the older medieval tradition, see Peter Lombard, Sententiarum Libri Quatuor, in 192 PATROLOGIAE CURSUS COMPLETUS, SERIES SECUNDA 878, 879 (J. Aleaume ed., Paris, J.-P. Migne 1855).

48. Cf. 2, pt. 1 WERNER SOMBART, DER MODERNE KAPITALISMUS 27-28 (2d ed. 1917) (discussing "freebooting" ethic among early merchants). 
then he must be expelled from the Temple." See also Cassidorus on Psalm 70 , verse $17 .^{49}$

Similar things, Udemans noted, had also been said by Thomas Aquinas. ${ }^{50} \mathrm{He}$ continued:

This, and the like hard and rough manner of speaking, will easily leave the pious merchant disturbed in his conscience and make him restless, especially when these passages are printed alongside the words of Sirach, chap. 26, verse 27: A merchant can scarcely guard himself against doing evil, and a shopkeeper against sinning. ${ }^{51}$

Disturbed in their consciences and restless is surely how merchants of the day felt, reading these passages. Nor was it only in Udemans's book that they read them: These distressing passages were common fodder for the moral literature of the day. One must imagine oneself a believing merchant of the early seventeenth century, exposed to something like the preacher Adam Westerman's wonderfully titled A Free Market for the People of Zion $(1628),{ }^{52}$ which, amidst lengthy denunciations of marketplace morals, repeatedly named Judas Iscariot as the classic merchant:

This Judas turns merchant, and having no other wares, he treacherously sells his own true Lord and Master with a kiss, in return for a vile penny and a shameful profit.... Oh misbegotten merchant! Lucrum in arca, damnum in conscientia, Mercedem in Gehenna. That is: Profit in the strongbox, damage in the conscience, reward in Hell. ${ }^{53}$

49. UDEMANS, supra note 46, at [2]-[3]:

Chrisostomus seyt Tom. 2. Homil. 38. fol. 999. edit. 1547 over die woorden Matt. 21. vers.

21. lesus gaende in den Tempel \&c. Hier mede (seydt hy) wordt te kennen ghegeven, dat een Coopman nauwelijck, of nemmermeer, den Heere kan behaghen: ende derhalven en behoorde gheen Christen, een Coopman te wesen, of indien hy dat wil wesen, soo moet hy uyt den Tempel geworpen werden \&c. Item, Cassiodorus ad Psalm. 70 vers. J7, by ons 71 vers. 15.

50. Id. (citing Aquinas 2.2. 77. art. 4). The cited text can be found at 2 ST. Thomas Aquinas, SuMMA THEOLOGIAE 1514 [pt. 2-2, question 77, art. 4] (Fathers of the English Dominican Province trans., 1947).

51. UDEMANS, supra note 46, at [3]: "Dese ende dierghelijcke harde, ende rauwe manieren van spreken, souden lichtelijek een vroom Coopman in syne conscientie verstellen ende ongherust maken, insonderheyt als hy daer by bedenckt de woorden van Syrach, cap. 26. vers. 27. Een Coopman kan hem swaerljck hoeden voor onrecht, ende eenen Kramer voor sonde." On the last-quoted passage from Ecclesiasticus ("Sirach" in the ordinary seventeenth-century Dutch citation form), see VINER, supra note 12 , at 36. For the older medieval tradition, see Baldwin, supra note 12, at 37.

52. ADAM WESTERMAN, VRYE IAER-MERCKT VOOR DEN VOLCKE ZION (Amsterdam, Hendrick Laurentz 1628), whose subtitle promised to "discover and punish the sins and horrors" of the marketplace, in order to further the establishment of a "free and eternal market, full of grace, in Christ Jesus."

53. Id. at $10[\mathrm{r}]-10[\mathrm{v}]$ :

Dese Judas wort een Coopman/ ende ghenen anderen Ware hebbende/ vercoopt verradelijck met eenen Cus sijnen eyghen getrouwen Heere ende Meester/ om eenen snooden Penninck ende schandelijcken ghewins wille. ... O onsalighe Coopman! Lucrum in arca, damnum 
"A merchant can scarcely hope to enter Heaven"; "Profit in the strongbox ... reward in Hell." These are frightening propositions, and they are done up in the sort of jingly Dutch rhymes that must have lodged themselves in the head of any Dutch reader. Had the "pious merchant" never heard anything else, we might well wonder how Dutch commerce could have flourished.

But the "pious merchant" did hear other things. Indeed, the tale I wish to tell is precisely the tale of how other things came to his ear.

In particular, it deserves emphasizing, the merchant heard other things from Udemans, Westerman, and their ilk themselves. Dutch Calvinist tracts, like much of the theological literature of the Middle Ages, ${ }^{54}$ did not condemn commerce as such. As Westerman put it, in a typical mix of primitive economics and Dutch saying-mongering:

I do not wish to rebuke or impede honorable commerce, knowing full well that neither the economy, nor the Republic itself, can exist without it. One man must live from another, just as one fish must live from another: As a poet well says: Non omnis fert omnia tellus: Not every piece of land yields every kind of fruit. ${ }^{55}$

Udemans, and others too, took much the same line. ${ }^{56}$ Dutch Calvinist preachers did not hate commerce as such. They were concerned much more with the immorality of a few specific commercial practices than with making sweeping denunciations of commerce more broadly.

\section{IV}

But there were specific practices that were immoral in the eyes of Dutch Calvinist preachers. It is on some of those specific commercial practices that I would like to focus, comparing the sorts of moral evils that Dutch preachers denounced, and the way that they denounced them, with patterns of denunciation elsewhere in Europe. For the reality is that, ugly as the language of Dutch Calvinist authors could be, they were much more tolerant of critical moral norms of commerce than were Christians elsewhere. If we understand the magnitude of this Dutch difference, we will understand how much the

in conscientia, Mercedem in gehenna. Dat is/ Winst in de Kiste/ schade in de conscientie/ Loon in der Helle.

54. KALB, supra note 12 , at 150.

55. WESTERMAN, supra note 52, at 4[v]:

Den Rechtveerdighen Coophandel en wil ick oock niet bestraffen/ noch beswaren/ wel wetende buyten dien de ghemeene Huys-stant ja Republijcke niet te connen bestaen/ ende de eene Mensche van den anderen/ghelijck de eene Visch van den ander te moeten leven: want ghelijck een Poeet wel seyt: Non omnis fert omnia tellus: Elck Landt draeght niet alle Vruchten.

56. See, e.g., Petrus Wittewrongel, Het Tweede BoECK VAN DE OECONOMIA Christiana Ofte ChRISTElicke HuYs-Houdinghe 602 (Amsterdam, Voor de Weduwe van Marten Jansz. Brant, en Abraham van den Burgh 1661). 
market world of Holland had begun to depart from the Christian tradition of the Middle Ages, and how growingly receptive it had become to the teachings of Roman law.

I am going to start with a topic that was central to the sense of evil in the markets, and that has accordingly been much emphasized by historians of economic ethics: the theory of just price.

The theory of just price, which played a long and centrally important role in Christian thought, held that all goods had an objectively correct price, and that it was sinful to profit by buying or selling at any price other than the correct one. At the heart of this theory was a view of the world that, in essence, lives with full emotional force for Americans only in the law of insider trading: the view that it was fundamentally wrong for one contract partner to get the better of another by selling high or buying low. ${ }^{57}$ This view is difficult for us to grasp: To us, such behavior between trading partners is unproblematically permissible in almost all contexts, and we have a hard time grasping the moral depth of the problem in the law of the older Christian world. Yet in the law of earlier centuries, this question was as bitterly troubling as is the question of insider trading now; and it carried with it the same vague anxieties about the market that inform our public debate about insider trading - the same firm, but inarticulate, conviction that evil is afoot in the market.

As a number of medieval historians have emphasized, this was a matter on which Roman and Christian traditions sharply differed. Both Roman and Christian traditions started from the assumption that all goods had, by some measure, an objectively correct price (as everyone started from that assumption until the marginalist revolution). But Roman and Christian texts differed sharply on the question of whether it was permissible to deviate from that correct price. On the most liberal end of the spectrum, readers of Roman texts found a famous, and to traditional minds highly sinister, classical pronouncement: "with regard to price, contract-parties have the natural right

57. Compare the arch comments in Basic, Inc. v. Levinson, 485 U.S. 224, 255 (1988) (White, J., concurring in part and dissenting in part) (citation omitted):

To define the term "integrity of the market price," the majority quotes approvingly from cases which suggest that investors are entitled to "rely on the price of a stock as a reflection of its value." But the meaning of this phrase eludes me, for it implicitly suggests that stocks have some "true value" that is measurable by a standard other than their market price. While the scholastics of medieval times professed a means to make such a valuation of a commodity's "worth," I doubt that the federal courts of our day are similarly equipped.

The sense that there may be a just price has remained stronger in Europe than in America. See James Gordley, Equality in Exchange, 69 CAL. L. REV. 1587 (1981). Indeed, the Dutch material that I trace here belongs very much to this general European tradition. My argument is not that there is no just-price tradition to be found any longer, but that the sense, typical of older Christianity, that it is sinful to deviate from just price, has waned. 
to overreach each other." ${ }^{\text {58 }}$ Alongside this classical rule, however, came a later and more restrictive rule: the famous late-antique doctrine of laesio enormis, which allowed a seller to rescind the sale of a tract of real property for less than half its true value..$^{59}$ In the European tradition, jurists extended the rule of laesio enormis beyond the case of real property, and beyond the class of sellers, making of it a general limitation on the principle of caveat emptor (and caveat vendor) wherever misrepresentations led to mispricing of at least half the true value of the subject goods. After late antiquity, the Roman legal tradition thus continued to permit deviations, but only as long as they did not exceed half the correct price.

But for the purely Christian tradition, even allowing mispricing up to half the "true" value of goods ran strongly contrary to urgent moral needs in the government of markets. Here stood, against the texts of Roman law, a fiery classic text of St. Paul, belonging possibly to the earliest piece of Christian writing we possess. ${ }^{60}$ In the midst of a passage principally about sexual ethics, Paul seemed to condemn "overreaching" in contracts, and in the harshest terms:

This is the will of God, that you should be holy: you must abstain from fornication; each one of you must learn to gain mastery over his body, to hallow and honor it, not giving way to lust like the pagans who are ignorant of God; and no man must overreach his brother in business transactions, or invade his rights, because, as we told you before with all emphasis, the Lord punishes all such offenses. For God called us to holiness, not to impurity. Anyone therefore who flouts these rules is flouting, not man, but God who bestows upon you his Holy Spirit. ${ }^{61}$

The standard Latin version of Paul's text used a technical Roman contract law term for "overreaching," 62 and from late antiquity onward, Christian

58. Statements of the classical rule can be found at D. 4, 4, 16, 4; D. 19, 2, 22, 3. See FrANCIS DE ZULUETA, THE ROMAN LAW OF SALE 19 (1945). For the Roman rule of caveat emptor, see JoHN CROOK, LAW AND LIFE OF ROME, 90 B.C.-A.D. 212, at 181 (H.H. Scullard ed., 1967).

59. See C. $4,44,2 ;$ C. 4, 44, 8. For a very fine brief introduction, see REINHARD ZIMMERMANN, THE LAW OF Obligations: RoMAN Foundations of THE Civilian TRADITION 255-70 (1990), with citations to much further literature.

60. For the dating, see, for example, TRAugotT HOLTZ, DER ERSTE BRIEF AN DIE THESSALONICHER 19-20 (1986).

61. 1 Thess. 4:3-8 (slightly altered from New Century Bible).

62. The Greek term, translated here as "overreach" was hyperbainein, translated in the Vulgate as circumvenire. See NovUM TESTAMENTUM GRAECE 520 (Eberhard Nestle ed., 1975); and BIBLIA SACRA, IUXTA VulgataM CLEMENTINAM 1145 (Alberto Colunga \& Laurentio Turrado eds., 1977), translating Paul's text into Latin as: "et ne quis supergrediatur, neque circumveniat in negotio fratrem suum." The exact sense of the original Greek is not easy to determine. For conflicting views, holding respectively that Paul was speaking of sex and of commerce, see, for example, I. HOWARD MARSHALL, NEW CENTURY BIBle CommentaRY: 1 AND 2 ThesSAlonians 111 (1983); and HoltZ, supra note 60, at 161-62. What Paul actually meant in his original text has, of course, no bearing on my general topic, which involves only how Paul was understood in later centuries. 
theologians built, on Paul's text (supplemented by important arguments from Aristotle), a substantial body of just-price theory, which condemned the Roman rule on overreaching as unbrotherly, un-Christian, and deeply dangerous to the soul. $^{63}$

In developing this tradition, medieval theologians were, to be sure, careful not to deny that Roman law had all of its authority. But they insisted that Roman law was trumped by a divine law that dictated obedience to higher principles. The leading passage came from Thomas Aquinas. Following standard medieval practice, Aquinas replaced the Roman terms for overreaching with the harsher word "deception":

[E]ven human law demands restitution to be made, for instance if a man be deceived in regard to more than half the amount of the just price of a thing.

On the other hand the Divine law leaves nothing unpunished that is contrary to virtue. Hence, according to the Divine law, it is reckoned unlawful if the equality of justice be not observed in buying and selling ....64

This tradition developed throughout the later Middle Ages, giving rise to a rift between theologians, who strongly resisted the teachings of Roman law, and canon lawyers, who were more receptive to those teachings. ${ }^{65}$ It reached its maturity in the work of the Spanish neo-Scholastics, who published subtle manuals, for both confessors and merchants, that laid out the danger that hung over the souls of merchants who sought profit too eagerly. ${ }^{66}$ Many of the canon lawyers working in this tradition showed an acute and sensitive knowledge of market relations, and an eagerness to see the world from the merchant's point of view: As scholars have shown, the medieval tradition of just-price theory was the home of some intriguing economic reasoning, particularly toward the end of the Middle Ages, as Christian authors came to agree that the normal just price was the prevailing market price; that the market price was determined through a dynamic of scarcity and demand; and that the greatest danger to just price was monopoly. ${ }^{67}$

In fact, many medievalists, noting the economic sophistication of latemedieval authors, have been ready to conclude that the Christian tradition had definitively accepted market morality at the end of the Middle Ages. ${ }^{68}$ That

63. See VINER, supra note 12, at 81-85. For a further discussion, see A. Wacke, Circumscribere, gerechter Preis und die Arten der List, 94 ZEITSCHRIFT DER SAVIGNY-STIFTUNG FÜR RECHTSGESCHICHTE (ROMANISTISCHE ABTEILUNG) 183, 186 (1977), and the literature cited there.

64. 2 AQUINAS, supra note 50 , at 216.

65. See the classic discussion of Baldwin, supra note 12, at 31-74.

66. See now the important discussion of GORDLEY, supra note 12.

67. See Gordley's suitably measured and skeptical discussion, id. at 97-98.

68. Again, this argument will be most familiar to American readers through Simpson, supra note 12, at 537 . 
conclusion is, however, surely overhasty. Theologians, even at the height of their powers as economists, never doubted that there was a just price, ${ }^{69}$ and proof of just price remained a matter that could pose great peril to merchants. ${ }^{70}$ Moreover, I believe a case can be made that such liberalization as took place in the later Middle Ages was followed by a backlash; as we shall see, authors in most of Europe, in the later sixteenth and seventeenth centuries, expressed noticeably more uneasiness about just-price questions than did their late-medieval and early-sixteenth-century predecessors.

Most importantly, theologians and canon lawyers, far back into the Middle Ages and well into the seventeenth century, never doubted that taking "intentional" advantage of the more liberal Roman rules was sinful." This meant that throughout the Christian Middle Ages and into the following centuries, there remained a real and palpable threat to the soul of any merchant who was conscious of driving hard bargains-a threat present even to the merchant who merely wondered, in moments of fear and trembling, whether he had ever "intentionally" profited too much. This was a threat of inescapable importance for anyone who wishes to understand the behavioral foundations of commerce. The threat to the soul was directly communicated to medieval merchants, as Winfried Trusen has emphasized, through one of the most powerful means of moral suasion available to the Church: the practice of confession. ${ }^{72}$ In the medieval theological tradition, Roman law, whatever its authority, did not govern the forum internum, the internal court of conscience, presided over by the confessor. ${ }^{73}$ It was in the separate jurisdiction of the confessional, accordingly, that the teachings of Roman law were neutralized. And vigorously so: A merchant's confessor was directed to remind him that it was potentially a mortal sin to take advantage of the rules of Roman law. ${ }^{74}$

69. Nor did they doubt, as Gordley observes, that the "just price" could properly be set by the public authorities. See GORDLEY, supra note 12, at 97.

70. This is because just price, even if theoretically determined by forces of scarcity and demand, would typically have to be proven in court by the testimony of local witnesses. See, e.g., 2 A. LEIVA DIDACUS CoVARruVIaS, VARIARUM EX IURE PONTIFICIO, REGIO, \& CAESAREO RESOlUTIONUM LIBRI IIII at 12[r] [lib. 2, cap. 3, no. 3] (Salamanca, In aedibus Dominici à Portonariis 1570); cf. Baldwin, supra note 12, at 53 (discussing requirement of witnesses). Of course, there would have been innumerable variations. See, e.g., GERAUD DE MAYNARD, ABREGE DU RECUEIL DES ARRESTS NOTABLES DE LA COUR DE PARLEMENT DE TOLOSE 56 (I.I.D.P. ed., Toulouse, Amaud Colomiez 1657); F. MonTE SAN SAVARINO, TRACTATUS DE EMPTIONE [questions 8 \& 10] (Siena, Impressus per Magistrum Henricum de Colonia 1489) (noting assumption of just price, with burden of proof in determination on adversary). Nevertheless, it must often have been the case that local witnesses were called. The danger to merchants of any proceeding in which witnesses were called, at least in troubled times, is plain.

71. Baldwin, supra note 12 , at 55-57 (on canon doctrine).

72. Winfried Trusen, Forum Internum und gelehrtes Recht im Spätmittelalter, 57 ZEITSCHRIFT DER SAVIGNY-STIFTUNG FUR RECHTSGESCHICHTE (KANONISTISCHE ABTEILUNG) 83, 83-126 (1971).

73. KALB, supra note 12, at 140-49; WINFRIED TRUSEN, SPÄTMITTELALTERLICHE JURISPRUDENZ UND WIRTSCHAFTSETHIK 81 (1961).

74. See the summary of the treatment of medieval confessors' manuals, mostly but not entirely uniform, in KALB, supra note 12, at 149-56. 
It takes no great leap of the imagination to understand that, at the very least at the margins ${ }^{75}$ this practice discouraged the development of commerce.

Far back into the Middle Ages, then, long before the Dutch commercial revolution, the learned European tradition had regarded Roman law as justifying ugly and sinful market practices. Far back into the Middle Ages, Europeans had attempted, as it were, to combat infection by the Roman rules, using the powerful instrument of the confessional. Outside the confessional, too, Europeans promulgated secular just-price legislation: ${ }^{76}$ This history, like the history of virtually any aspect of European life, is a history in which Christian and secular norms were intricately intertwined and intergrafted. The existence of this medieval tradition, in and of itself, would do a great deal to justify the notion that Roman law represented a moral menace in premodern minds. For the idea of any possible liberalization of the just-price tradition drew always on the authority of Roman law; and when liberalization took place (as it surely did at least in the theory of some authors ${ }^{77}$ ), it took place amidst citations of Roman texts.

But the best evidence for the moral impact of Roman law on this matter comes from Holland, scene of the great commercial revolution. For as the Dutch commercial revolution gathered steam, the old tradition of conflict between Roman and Christian rules took a turn toward the Roman side.

The Pauline tradition did not simply die, needless to say. Changes so abrupt do not take place, particularly in settings as deeply Christianized as seventeenth-century Holland. ${ }^{78}$ The sense that there was evil afoot in the market did not completely vanish; far from it: We have already seen that Udemans, Westerman, and folk like them continued to feel burning doubts about market relations. These doubts were, indeed, given symbolic form in the layout of the bustling Amsterdam grain bourse, at the center of which stood an alms box, as though to declare to a skeptical world that charity had not been forgotten in the commercial Netherlands. ${ }^{79}$ But alms boxes

75. I say "at the margins" conceding willingly the point of Baldwin, supra note 12 , at 10 , that enforcement through the confessional "gives no assurance that the penitent merchant followed the ideals of his confessor."

76. See, for example, the citations to the French case cited infra note 98 , and the Italian case cited infra note 101.

77. See the very learned discussion of Gerber, supra note 12.

78. As Lichtenauer remarks, the Roman rules remained "the toughest nut to crack." LiCHTENAUER, GESCHIEDENIS, supra note 37 , at 20-21.

79. As a seventeenth-century tourist guide to Amsterdam described the grain bourse, in both Dutch and, for foreign tourists, French, in a passage well worth quoting:

't Gebouw is vierkantig/ aan drie zijden geslooten/ en tegen de Straat open. In " $t$ midden heeft het/ even als de groote Beurs/ een open Plein/ en aan drie zijden Galderijen/ die op 52. ronde houte Pilaaren rusten.... Veele Kooplieden en makelaars hebben "er onder de Galderijen hun kaasjes/ om de Koren-monsters in te bergen. In ' $t$ midden/ aan d'opene zijde/ staat een konstige kopere Bos op een swaare kopere Pedestaal/ in de welke d'Aalmoesen voor d'Aalmoeseniers Armen vergaderd worden. 
notwithstanding, the old Christian anxieties about pricing began to ease in the Dutch seventeenth century, and the Roman texts became more widely diffused and accepted. In particular, the Dutch literature displayed a shift of major, and neglected, importance-neglected both by legal historians and by critics of the Weber thesis: Just price began to give way, in the Dutch literature, to regulation of quality.

To see this, we must look to two different sorts of literature: the moralizing literature and vernacular legal handbooks.

Let us begin by comparing our Dutch Calvinist moralists with the Christian authors of other places, and in particular with the authors of confessors' manuals. In most of the rest of seventeenth-century Europe, Christian authors presented merchants and their confessors with standard canon doctrine, drawn from the Spanish neo-Scholastics. This literature continued to emphasize just-price theory, while making some careful intent-based distinctions. An early-seventeenth-century Italian could accordingly expect to hear from his confessor that to charge anything but the just price was to cheat his neighbor, whom God commanded him to love. ${ }^{80}$ Non-Dutch technical books on commercial practice continued to work very carefully over just-price restrictions. Thus one standard work used all over Europe, Benvenuto Stracca's On Commerce, ${ }^{81}$ spent much time preaching the limits on pricing dictated by the Pauline tradition, and in ways bizarre to us. For example, Stracca warned merchants vigorously against buying goods and contracting to resell them for a higher price. That kind of profit seeking was dangerous to the soul. Stracca listed many other comparable dangers, too, most of which, to the modern ear, clearly belong to a premodern world. ${ }^{82}$

But Holland of the commercial revolution broke out of this pattern. Dutch Calvinist authors continued to cite the famous passage of St. Paul, as

The building is square, closed on three sides, and open to the street. In the middle it has an open court, just like the great Bourse [i.e. the Stock Exchange], and on three sides it has galleries, which rest on 52 round wooden pillars. . . Under the galleries, many merchants and brokers have their chests, in which they keep their grain-samples. In the middle, on the open side, stands an artfully wrought copper box [tronc in facing French text] on a heavy copper pedestal, in which alms are gathered for the Almoners' poor.

JAN VEENHUYSEN, ALLE DE VOORNAAMSTE GEBOUWEN DER WITTVERMAARDE KOOPSTAD AMSTERDAM illus. 43 (Amsterdam, H. Sweerts et al. n.d. [1675?]). Noteworthy here is not only the symbolically prominent gathering of alms, but also the manifest existence of a highly competitive market in grain.

80. Cf. SigISMUND SCACCIA, TRACTATUS DE COMMERCIIS ET CAMBIO 230 (Geneva, Sumptibus loannis Hermanni Widerhold 1664) (not permissible in forum of conscience to deceive "your neighbor, whom you must love as yourself"). See generally the same passage for some of the careful distinctions drawn in this tradition.

81. Benvenuto Stracca de Ancona, De Mercatura seu Mercatore Tractatus (Venice, Apud Ioannem Baptistam \& Melchiorem Sessam fratre ca. 1555).

82. Id. at $10[\mathrm{v}]-11[\mathrm{r}]$ [pt. 1, para. 34]. For Stracca's influence in France, see, for example, JEAN HILAIRE, INTRODUCTION HISTORIQUE AU DROIT COMMERCIAL 323 (1986). Cf. LICHTENAUER, GESCHIEDENIS, supra note 37, at 55; WILHELM F. LICHTENAUER, DE GROEI VAN DE ORGANISATIE-GEDACHTE (1942). Stracca was, of course, also used in Holland as elsewhere, on many questions. See LiCHTENAUER, GESCHIEDENIS, supra note 37 , at 44. 
Christians had done for centuries. But compared with contemporaries anywhere else, they had remarkably little to say about the psychologically charged issue of pricing. In place of just pricing, the Dutch Calvinist literature emphasized something new, and something that to us seems much more comprehensible: the policing of the quality of goods.

Thus Westerman, our most ferocious Calvinist author, saw fit to mention just price only very briefly. To him, St. Paul's famous passage was not primarily about the anxiety-laden question of price. It was about misrepresentation of quality. Like other Christians, Westerman rendered Paul's "overreach" as "trick." Like other Dutch authors, he highlighted the cases of pepper and grain, the most important commodities in the Dutch trading empire:

When merchants come to the market, they forget the saying of St. Paul, This is the will of God, namely your savior, that nobody invade his brother's rights or trick him [1. Thess. 4, 6]. Just as there are no activities engaged in by men, in which sin does not in some measure appear, so is sin also practiced in commerce, be it through lying, deceiving each other about wares, getting the better of each other with short weights or measures, or cheating each other with regard to price, so that sin sprouts out of this or that cranny or crevice. For many have committed evil for gain. ... As a stake is driven firmly into a fissure in a wall, so sin is wedged in between buyer and seller. [Sirach. 27. v. 1.] And at the end of the previous chapter, Sirach says: A merchant can scarcely guard himself against doing evil, and a shopkeeper against sinning. [Ch. 26, v. 27.]

You will discover, in the market, that many, for whose sake the Cross was erected, think to themselves, "It is a free market, ergo I am free to do anything." Therefore they sell chaff as grain, mouse-droppings as pepper, an old blind nag as a healthy stallion, a measly pig as though it were a clean one; they use false rods, weights, and measure; they mix bad wares in among the good, and fill their stalls and shops, from morning to night, with lies and trickery, and embellish what they do with pretty words, and confirm it all with mighty words and oaths. It is a wonder that their stalls and shops do not burst into flames above their heads. ${ }^{83}$

83. WESTERMAN, supra note 52 , at $70[\mathrm{v}]-71[\mathrm{v}]$ :

Als nu dese in de Marckten ghecomen zijn/ vergeten wort by haer de spreucke Pauli dit is de wille Godts, namelijck uwe heylichmaeckinghe, dat niemant synen Broeder verdrucke, noch en bedrieghe. [1.Thess.4.6.] Ghelijck alser ghene handelinghen onder den Menschen ghepleecht en werden/ sonder dat de zonde sich mede daer onder vertoont/ soo ist dat dat ooc mede in den Coophandel de zonde geoefent wert/ 'tzy met lieghen/ malcanderen met de Waren te bedrieghen/met schaersse Wicht ofte Mate te veronghelijcken/ ofte in den prijs malcanderen te becoopen/ soo dat de zonde aen dees of d'ander cante uyt berst. Want ommegoets [sic] wille doen vele onrecht, ghelijck als eenen Naghel inden Muer tusschen twee Steenen steeckt, alsoo steeckt ooc de zonde tusschen den coper ende vercoper. [Syr.27.v.1.] Ende int eynde vant vorighe Capitt. spreeckt Syrach. Een Coopman can hem swaerlijck hoeden voor onrecht, ende een Kramer voor zonde. [Cap. 26. 27.]

Men sal inde Merckten bevinden/ dat menich om dat het Cruys opgheslaghen is/ meynt het is een vrye Merck/ ergo hy mach alle dinck wel vry doen/daerom vercoopen 
This is deeply, piously, and (to our ears) almost flamboyantly Christian; and it still mentions price, of course. But it is wrong to say what critics of Max Weber, including most recently Simon Schama ${ }^{84}$ have repeatedly said: that the tradition to which Westerman belonged simply repeated what Christian theologians had said before. Deeply Christian though Westerman was, there is surprisingly little in this passage (or elsewhere in his writings) that shows the old, and centrally important, anxiety about pricing-the anxiety that in every non-Dutch author stirred paragraphs upon pages about just price. The prime evil Westerman saw in the market was an evil involving misrepresentation of quality and the regulation of weights and measures.

The same is true of Udemans, and of other moralists as well, from whom we may quote numerous passages (typically mentioning the leading Dutch example of grain). For Udemans, unlike contemporaries in places like Italy, ${ }^{85}$ the just-price problem survived principally as a problem of monopoly; and the prime evils of the marketplace about him were short weighting and nonmerchantability, second only to the declaration of bankruptcy (our next topic) as evidence of moral collapse. Merchants endangered their souls, Udemans wrote, first of all:

through false weights, rods, and measures. Here the shopkeepers and small merchants run the greatest risk [of temptation], since they deliver and make sales using their own weights, rods, and measures, which they keep at home: whereas the great merchants are accustomed to make delivery of their bales, large crates, quarters, etc.,

Caff voor Coorn/ Muyse-dreck voor Peper/ eenen ouden blinden Guyl voor een gesonden Hengs $/$ een gortigen Vercken voor eenen reynen/ ende ghebruycken een valschen Ellen/ gewichte ende Matel goede ende quade Waren onder malcanderen mengen/ ende vanden morgen tot den avont sijn Craem ende Winckel met liegen ende bedriegen vervullen/ ende sulcx onder liefelijcke woorden stofferen ofte met hooghe woorden ende eden bevestighen. Wonder dat haer den Craem ende Winckel boven haren Hoofde niet af en brandt.

The "free" character of the Dutch market deserves some explication here. Following a tradition established in Antwerp, the market in Amsterdam was "free" in the sense that, to quote a 1644 authority,

Amstelredam is een Stadt, principalyck bestaenden by den Coop-handel; soo staet allen persoonen vry, zy zyn Poorters, Inwoonders, of Ingesetenen der selver Stede; ofte oock uytheemsche personnen, in vreemde Landen, Coninckrycken, ende Heerlyckheyden woonende; haere waeren, ende Coopmanschappen binnen der voorsz. Stede te brengen, koopen, verkoopen, ende vermangelen ....

Amsterdam is a city that exists principally by commerce, and so it stands free to all persons, be they citizens, inhabitants, or residents of the city; or also aliens, living in foreign lands, kingdoms, and principalities; to bring, buy, sell, and trade their goods and business within the aforesaid city ....

GeraRd RoOSEBOOM, ReCUEIL VAN VERSCHEydE KEUREN, EN COUSTUMEN; MitSGaders MaNieRE VAN PROCEDEREN, BINNE DER STEDE AMSTERDAM 214 (Amsterdam, Gerrit Jansz. 1644) (citing Custom of Antwerp). That is to say, the right to trade was free to all. Amsterdam was also "free" in the sense that slavery was not tolerated: According to Rooseboom, slaves were free upon their entrance into the city. Id. at 186. But see id. at 207,214-15 for the legal limitations on the freedom of women and on the free practice of crafts.

84. SCHAMA, supra note 40 , at 330 (discussing Udemans); see also Beins, supra note 45.

85. See infra note 101 . 
at the official city scales. But they are also in the habit of marketing substandard wares, of using false or inflated money, of taking a usurious return on bills of exchange; of entering into the most crafty of contracts: engaging in monopoly - that is, when merchants join together to maintain an unjust price for goods, to the injury of the community; but above all, they sin when they practice bankruptcy ...86

We may similarly cite Petrus Wittewrongel's Oeconomia Christiana ("Managing a Christian Household and Business"), ${ }^{87}$ which included more of the old just-price reasoning than did the work of Udemans or Westerman (though again in a distinctly mild version), but which too focused heavily upon the quality of goods, weights, and measures. ${ }^{88}$ If we read these texts with some literary sensitivity, and compare them to the fulminations of the non-Dutch literature on price, we can see that a critical change was underway. For these Dutch moralists, the first great problem of the market was not incorrect pricing, but nonmerchantability and short weighting. Where before the Christian tradition had been a tradition of vague anxiety about the market, difficult for us to grasp, it now became a tradition of market policing of a kind familiar to every student of modern commercial law. (Dutch statutory and customary law of the seventeenth century, too, focused on the regulation of weights and measures. ${ }^{89}$ ) This was a development of real consequence, and it deserves some attention from historians of commercial law. The evolution of commercial law, we might say, as we find it in the Dutch moral literature, did not express itself in a movement from regulation to nonregulation. It

86. UDEMANS, supra note 46 , at $10[\mathrm{v}]$ :

valsch gewichte, elle, mate, daer de Cramers ende smalle Coop-luyden meer perijckel van hebben/ om datse de waren meest leveren ende uytventen met haer eyghen ghewichte, elle, mate, die sy binnen s'huys hebben: daer de groote Coop-Luyden hare balen, ende groote packen/ quartelen \&c. pleghen te leveren in stadts-bilance: maer sy wordt oock ghepleecht met vervalschinghe vande ware, met vervalschinghe, of steygheringe vande munte: oock met onbehoorlijcken woecker vande wissel: met arch-listighe contracten: met Monopolie, dat is/ wanneer de Coopluyden tsamen couten/ om de waren te houden op eenen onbillicken prijs/ tot last vande goede Gemeynte: maer vooral met banquerouterie ....

87. WITTEWRONGEL, supra note 56.

88. See id. at 602-07. Wittewrongel's work certainly spent more time on issues of price than did those cited in the text, see id. at 605 (counseling merchants to take only an "honest profit"), but, I think it can be said on a fair reading, showed the same larger and more emphatic interest in questions of quality and weights and measures that figure so prominently in the Dutch literature of the day. See generally id. at 602-05.

89. This is, of course, broadly true of Europe. See, e.g., JEAN IMBERT, LA PRACTIQUE IUDICIAIRE CIVILE ET CRIMINELlE, RECEUË \& OBSERVEe PAR TOUT LE ROYAUME DE FRANCE (Paris, Louis Feuge 1627). It appears, however, to have attracted particular attention in Holland. Compare the later seventeenthcentury requirement that all weighable goods be weighed at the official city scales. See, e.g., LE MOINE DE L'ESPINE, LE NEGOCE D'AMSTERDAM 47 (Amsterdam, Pierre Brunel 1710). This seemed remarkable enough to contemporaries to deserve discussion in guidebooks, which led tourists to the great scales to be found in Dutch cities for the use of merchants. VEENHUYSEN, supra note 79, illus. 40, for example, went out of his way to note that merchants were required to consummate their transactions at one of the two great city scales of Amsterdam. 
expressed itself in a movement from regulation of price to regulation of quality.

Now this movement was obviously one that we must interpret with some care. Price and quality are two sides of the same coin; to sell goods of too low a quality is, of course, in many cases simply to sell them for too high a price, as some Christian authors observed. ${ }^{90}$ And indeed, from the beginning, the Christian theological tradition treated both questions of price and of quality as raising similar issues; ${ }^{91}$ the shift I point to was a shift within the concept of "overreaching," not away from the concept of "overreaching." Nevertheless, it was an important shift. We could state its importance as a shift in the scope of the rule, by saying that the shift meant that prohibitions on overreaching would capture fewer transactions: Only transactions in which one party actively deceived the other about the subject goods would be characterized as involving "overreaching." We could also-more importantly from my point of view-characterize the shift in sociological terms. For as the moralizing literature turned its fire from price to quality, it ceased by that very token to condemn hard-bargaining behavior. The shift from regulation of price to regulation of quality opened the door to a style of merchant behavior that had long been condemned as grasping and wrong. ${ }^{92}$

It is no surprise that this shift was accompanied by a marked openness to Roman law. At the same time that the moralizing literature was turning from price to quality, Dutch vernacular law books displayed a discernible receptivity to the Roman rules, distrusted and combated for so long. Here I will take, as my prime example, Bernhard van Zutphen's Nederlandsche

90. See, e.g., SARAVIA DE LA CALle Beronense, INSTRUCCIÓN DE MERCADORES MUY PRovechoSA 17[r]-22[r] (1547); GERHARD OTTE, DAS PRIVATERECHT BEI FRANCISCO DE VITORIA 87-88 (1964).

91. See, e.g., 2 AQUINAS, supra note 50, at 212-20 (discussing price and quality).

92. In this regard, Dutch law came to approximate ancient Roman law. See Wacke, supra note 63, at 188-90. For the general Roman-law protection of expectations with regard to quality, by contrast to price, see also W.W. BUCKLAND \& ARNOLD MCNAIR, ROMAN LAW AND COMMON LAW: A COMPARISON IN OUTLINE 211 (F.H. Lawson ed., 2d ed. 1952); and, for Roman warranties, most recently, P. Apathy, Sachgerechtigkeit und Systemdenken am Beispiel der Entwicklung von Sachmängelhaftung und Irrtum beim Kauf im klassischen römischen Recht, 111 ZEITSCHRIFT DER SAVIGNY-STIFTUNG FUR RECHTSGESCHICHTE (ROMANISTISCHE ABTEILUNG) 95, 95-154 (1994), with citations to the newer literature. Roman-law protections with regard to quality were largely mounted through the Edilician Edict, which existed, as it were, alongside the protections of civil law. The mature medieval tradition, however, tended to assimilate the protections of this Edict to those of the civil law, creating a general law of implied warranty. See HERMANN DILCHER, DiE THEORIE DER LEISTUNGSSTÖRUNGEN BEI GLOSSATOREN, KOMMENTATOREN, UND KANONISTEN 222-24 (1960). The development that I trace here in some measure represents the completion of the development traced by Dilcher; where Roman law had a scattered collection of protections with regard to quality, treated separately from the issue of price, Dutch law tended to analyze both price and quality questions as falling under the general rubric of overreaching. $C f$. Zimmermann, supra note 33, at 185-87 (discussing later Dutch developments). Wacke correctly characterizes the underlying issue as one of the acceptability of hard-bargaining behavior. See Wacke, supra note 63, at 198-99, with further citations on dickering behavior in antiquity. For a dramatic representation, showing perhaps how deep Dutch assumptions about bargaining behavior ran, see the lovely seventeenth-century Dutch tile, illustrating the Roman law of contract with a scene of marketplace dickering, reproduced in J.E. SPRUIT, RECHTSGELEERDE MUURBLOEMPJES UIT DE 17 EEEUW. CURIEUS VERGLASSDE WANDTEGELS MET TAFELEREN UIT DE PANDECTEN 34 (1989). See also id. at 35 (commentary). 
Practyque, ${ }^{93}$ an alphabetized guide to Dutch law that first appeared in 1636. Zutphen's book belonged to a Europe-wide genre of legal literature called "Practica," vernacular handbooks that communicated the teachings of the Latin Middle Ages to a market of literate lay readers and small-time practitioners. ${ }^{94}$ The Nederlandsche Practycque seems to have been the dominant Dutch product for that market: It went through an unusually large number of printings and editions, and many copies still survive in libraries around the world..$^{95}$ As such, it is a peculiarly valuable source for tracking the nature and course of the vulgarization of law in commercializing Holland.

It is an important datum, then, that Zutphen treated overreaching as regards price in a wholly Roman way ${ }^{96}$ - something that set him apart not only from the theologians of the Middle Ages, ${ }^{97}$ but also from most non-Dutch Practica authors of his own day. The non-Dutch literature, whether Spanish, Italian, or English, uniformly condemned price overreaching, in traditionally Christian terms borrowed from the sixteenth-century scholarship of the Spanish canon lawyers. ${ }^{98}$ The great English-language vernacular book

93. BERNHARD VAN ZUTPHEN, NEDERLANDTSCHE PRACTYCQUE VAN VERSCHEYDEN DAGHELIJCKSCHE SOO CIVILE ALS CRIMINELE QUESTIEN (Leewarden, Gysbert Sijbes 1655).

94. See E. Holtöfer, Die Literatur zum gemeinen und partikularen Recht in Italien, Frankreich, Spanien und Portugal, in 1 CoING, HANDBuCH, supra note 38, at 318, 318-21.

95. Alfred Söllner, Die Literatur zum gemeinen und partikularen Recht in Deutschland, Österreich, den Niederlanden und der Schweiz, in 2, pt. 1 CoING, HANDBUCH, supra note 38, at 501, 609, lists seven editions.

96. Cf. S.J. Fockema ANDREAE, Het OUd-NederlandsCh Burgerlijk ReCht, TweEde DeEl 32 (1906); Christoph Becker, Das Problem der Austauschgerechtigkeit, in DAS RÖMISCH-HOLLÄNDISCHE RECHT, supra note 33 , at 201.

97. Though not necessarily from the learned Roman-law scholars of the Middle Ages (and Renaissance). Compare the contrast between the discussions of the Accursian Gloss and of François Douaren with that of Francisco de Vitoria noted in Wacke, supra note 63, at 190-91 n.25.

98. Borrowed from-but falling below the high level of sophistication and liberality of the Spanish tradition as traced by GORDLEY, supra note 12, at 96-102. For the dominance of the Spanish neo-Scholastics, see Miriam Turrini, "Culpa Theologica" $e$ "culpa iuridica": il foro interno all'inizio dell'età moderna, in 12 ANNALI DELL'ISTTTUTO STORICA ITALO-GERMANICO IN TRENTO 147, 153-54 (1986).

The tale in France, it should however be noted, was a considerably more complex one. On the one hand, merchants operating in France clearly faced some dangers. One 1627 Practique warned violators of just-price principles in France that, if their offense involved false weights and measures, they might in principle face the death penalty (though the author seems to have known of no cases where it was actually imposed.) See IMBERT, supra note 89, at 709. But other French authors could be astonishingly liberal. Most important is ANTOINE LOISEL, INSTITUTES CousTUMIERES 164 (Paris, M. Robin \& N. Le Gras 1665), which cheerfully announced that, "A thing is worth what it can be sold for." Loisel went further than most French vernacular authors. But many, like the Dutch, simply recited principles of Roman law. See, for example, PRUdent De SAinct Marie, La PRATIQue et Stil Iudiciaire 59 (Dole, A. Binart 1627), an author who, however, as a Burgundian, might be expected to resemble the Dutch in his views; or, from the southern city of Toulouse (with again some important regional variations), DE MAYNARD, supra note 70, at 56-57. More clearly nationally French in orientation, and advocating a much more purely classical Roman law than anything I have seen in the Dutch vernacular literature, is JEROSME MERCIER, REMARQUE DU DROIT FRANÇOIS SUR LES INSTITUTS DE L'EMPEREUR JUSTINIEN 376-83 (Paris, Nicolas le Gras 1688), a very learned discussion. Similarly complex is the discussion of GUY COQUiLLE, Institution au Droit des François, in LES OEUVRES DE M. GUY COQUILLE 146 (Paris, Anthoine de Cay 1646). The French tradition simply needs more discussion than I can give it here, beyond observing that at least some French authors were quite close to Dutch ones, and that in this respect, as in the treatment of cessio bonorum, see infra note 136, the Dutch belonged in some important ways to the French cultural circle; legal dialectology, as 
of the day, for example, Gerard Malynes's much-reprinted Consuetudo, vel lex Mercatoria, or The Ancient Law-Merchant (1622) tracked the canon-law tradition. Malynes told his merchant reader that, in pricing, a Christian was obliged to observe "equalitie in the value of things" and repeated a variety of canon-law economic doctrines. ${ }^{99}$ A much-reprinted Spanish-language handbook, Juan de Hevia Bolaños's Curia Philippica, harshly condemned merchants who even so much as asked a price higher than the just price. ${ }^{100}$ As for the early-seventeenth-century Italian literature, Giovanni Domenico Peri's 1638 Il Negotiante ("The Merchant") included unmistakably threatening language that told its reader that he was subject to unpredictable local sanctions if he violated local ideas of just price: The local town would determine the just price, he warned, "without regard to your cost, your risk, or your hardships."101

Zutphen's world was different. Unlike his English, Italian, or Spanish contemporaries, Zutphen offered the hard-bargaining Dutch merchant only comfort, and comfort drawn directly from Roman law. The classic Roman legal texts, rendered into Dutch, used the nastiest language of the medieval Christian tradition: They said that it was permissible to engage in "trickery," Bedroch. ${ }^{102}$ Yet when Zutphen came to the rubric Bedroch, far from engaging in Christian condemnation, he merely presented his Dutch readers with the doctrine of Roman law, in simplified form. Roman law permitted

it were, links Dutch-Roman law and French-Roman law together. For the importance of French influence in the Netherlands, see the remarks of R. FEENSTRA, Zur Rezeption in den Niederlanden, in FATA IURIS ROMANI 25, 25-26 (1974).

99. Gerard Malynes, CONSUetudo, Vel leX MERCatoria, OR THE ANCIENT LAW-MERCHANT 91 (London, Adam Islip 1622).

100. Juan de hevia Bolaños, Curia Philipica 306 (Madrid, Eugenio Bieco 1753) (1605).

101. Giovanni Domenico PERI, IL Negotiante 99 (Genoa, P.G. Calenzano 1638). For an earlier, and somewhat less ominous, Italian discussion in the neo-Scholastic tradition, see FraNCISCO GARzIA, TRATTATo DI TUTTI I CONTRATTI 118 (Brescia, Appresso Pietro Maria Marchetti 1589). A more liberal discussion can be found in a later authority. See GIOVANNI BATTISTA DE LUCA, IL DOTTOR VOLGARE 47 (Rome, Stamperia di G. Corvo 1673). For some monumental evidence of the threat that faced merchants, tourists may view the lion's mouth, inviting secret denunciations of "usurious contracts," in the Piazza dei Signori in Verona. See the description in Nino CENNI \& MARIA FIORENZA Coppari, I SEGNI DELLA VERONA VENEZIANA (IL SEICENTO) 55-60 (1992). For departures from just price as a form of "usurious contract," see Marc'Antonio Savelli, Pratica Universale 320 (Venice, Presso Paolo Baglioni 1715), a passage that also warns merchants that departures from just price are a form of sin.

It is possible that the Italian authorities of the early seventeenth century had become more restrictive than their predecessors-a development that would presumably reflect the impact of the Council of Trent. I must, however, leave the question of the sixteenth-century shift, if any, aside; but readers should see Turrini, supra note 98 , at $150-51$, noting a shift in the sixteenth century from a "medical" to a "juridical" concept of confession; and, contra, Christoph Bergfeld, Zur Jurisprudenz des forum internum, 16 IUS COMMUNE 133, 137, 143 (1989).

102. This followed medieval tradition, which altered the mysterious terms circumvenire and circumscribere to decipere, "deceive." For Betrug as the ordinary German rendering of deception, see KALB, supra note 12, at 117 n.32. 
wide deviations from just price; and the real call for regulation came in matters involving weights, measures, and quality of goods:

TRICKERY § 5: When one of the contract parties is tricked in the course of bargaining, he has no cause of action in consequence of that trickery against the party with whom he has contracted, as long as the trickery does not exceed half of the true value. However, when someone is tricked with regard to the quantity of the goods, he has an action for a supplement to the goods he has received, even though the trickery in question falls below half of the just price. Francisc. Marc. decis. 484. num. 29. 30. \& decis. 567. num. 7. Costal. ad 1. 16. ff. de minorib.

TRICKERY § 6: The seller is said to engage in trickery if he remains silent about some quality of the good, which, had he openly described it, would have led the buyer not to enter into a contract of sale; and the law will come to the aid of the buyer in such a case. Vincent. Caroc. decis. 1. nu. 8. Mascard. de probat. concl. 532. Menoch. de praesumpt. lib. 5. praes. 3. num. $73 .^{103}$

The first of these two paragraphs was a stripped-down version, aimed at laymen, of an elaborate medieval Roman-law doctrine; ${ }^{104}$ the second echoed developments in the thinking of learned Dutch jurists about protection of quality that somewhat altered ancient tradition while remaining generally faithful to Roman law. ${ }^{105}$ Neither was the most liberal interpretation of Roman law imaginable.

But if Zutphen's doctrine was far from classical Roman law, it was much further from the Christian tradition of condemnation that had so long dominated elsewhere in Europe-further in substance, and further in tone, too, for it was stated in the coolest language of the permissible. It is difficult to imagine a contemporary author in any other language informing his readers that they were permitted to "trick" others in any measure. There was nothing here about sin, nothing about risks to the soul, such as was to be found in other vernacular literatures. The same is true, moreover, of other Dutch

103. ZUTPHEN, supra note 93 , at 60 :

V. Als een vande contrahenten in het handelen bedroghen is/ soo en heeft hy ter oorsaecke van sodanich bedroch gheen actie teghens den ghene met dewelcke hy heeft gecontraheert/ indien het bedroch niet en zy boven de helfte van de rechte weerde: Dan so yemandt bedrogen is inde quantiteyt van het goedt/alsdan mach hy ageren tot supplement/ alhoewel het bedroch is beneden de helfte van de rechte prijse. Francisc. Marc. decis. 484. num. 29. 30. \& decis. 567. num. 7. Costal. ad 1. 16. ff. de minorib.

VI. Den vercooper wordt geseydt in bedroch to wesen/ indien hy verswijght eenige qualiteyt van het goet/ dewelcke soo hy gheexpresseert hadde/ de cooper niet en soude gecontraheert gheghadt hebben; ende wort daeromme sodanigen cooper gesuccurreert. Vincent. Caroc. decis. 1. nu. 8. Mascard. de probat. concì. 532. Menoch. de praesumpt. lib. 5. praes. 3. num. 73.

104. See KALB, supra note 12 , at 11 , with literature at 188-198. For the general faithfulness of the Dutch law to the long European tradition of Roman law, see Becker, supra note 96.

105. See Zimmermann, supra note 33 , at 187-88. 
vernacular guides to the law, though they certainly vary in some ways. ${ }^{106}$ (The same is also true, mutatis mutandis, of the most famous Dutch vernacular publication of the 1630s, Hugo Grotius's Inleiding tot de Hollandsche Rechtsgheleerdheyt ("Introduction to Dutch Jurisprudence"). ${ }^{107}$ ) Everywhere, the Dutch vernacular practical legal literature breathed the same air of chill immorality. Where the Christian theological tradition had always preached so vehemently the virtues of charity, these legal authors simply told their readers what they were permitted to do-and told them in their own Dutch language. The Roman-law tradition, after centuries of resistance, had begun to gain the upper hand.

\section{$\mathrm{V}$}

Something happened, then, in the Dutch law of overreaching, something that reflected a substantially changed attitude toward hard bargaining, and a substantially wider vernacular circulation of Roman rules. But if something happened in the Dutch law of overreaching, something even more dramatic happened in the Dutch law of bankruptcy. It is in the law of bankruptcy that we see Roman law at its most immoral, by the measures of the day. And it is in bankruptcy that we most clearly see Dutch law taking a new, Romanizing path.

To European authors everywhere in the seventeenth century, the declaration of bankruptcy was the single most scandalous phenomenon of commercial society. We may quote authors Italian, French, English, or German, all of whom regarded the declaration of bankruptcy as a ghastly evil. ${ }^{108}$ For that matter, we may continue quoting Udemans, our Dutch moralist. Even the evil of substandard quality took second place, in Udemans's mind, to the declaration of bankruptcy. Merchants sinned, he wrote:

above all, when they practice bankruptcy, that is, whenever they have assumed large capital obligations, or have allowed many honorable people to extend them credit, whether by giving their word, by signing a writing, or especially by circulating bills of exchange; only thereafter, wearing an attitude of shameless defiance, to shut themselves up within the walls of their house, and let good people go

106. See, for example, Martinus CaESAR, JUS HodieRnum, ofte HedendaEghs-Recht 216 (Amsterdam, Dirck Meyer 1656), which presented standard medieval Roman-law doctrine for a Dutchspeaking audience. For the doctrine presented there, and its roots in classical Roman law, see Wacke, supra note 63 , at $236-46$, with citations to further literature.

107. Hugo GRotius, INLEIDING TOT DE HollaNDSCHE RECHTS-GELEERTHEYd 381 (R.W. Lee ed., 1953) (1631). Although Grotius took time to wax philosophical over the Roman rule in a way that his more practically minded contemporaries did not. See id. at 511-13.

108. For the prevailing view, see, e.g., STRACCA, supra note 81 , the second part of which was Stracca's Tractatus de Conturbatoribus sive Decoctoribus, see id. at 335, perhaps best translated as "A Treatise on Deadbeats," which offered an elaborate and vitriolic discussion, see, e.g., id. at 358 ("Forsooth, deadbeats are the worst variety of human being ...."). 
begging, putting the word brusquely out that things are not going well, while at the same time they have frequently bought a great many goods on account only a short time before-goods that have now disappeared to parts unknown. This is an abominable species of theft . . . ${ }^{109}$

Yet as we shall see, even though Udemans denounced bancquerouterie as he understood it, he and his Dutch contemporaries took a dramatically more liberal, and more Roman, attitude toward insolvency than did Europeans elsewhere.

In particular, they took a dramatically more liberal attitude toward a Roman practice called cessio bonorum: ${ }^{110}$ the practice of ceding all one's goods, much as in a modern liquidation, in order to gain immunity from the normal sanction against insolvents, imprisonment. Cessio bonorum was permitted by a Roman statute whose ancient history is still rather mysterious; we remain unsure whether it was the work of Julius Caesar or Augustus." Whatever its true origins, early-modern Europeans did not doubt that it had been created by one of these luminous emperors, as an act of princely grace toward debtors, and had been further extended by later ancient emperors. " Cessio bonorum permitted debtors to escape imprisonment through a public ceding of all their goods, saving a few life necessities, to their creditors. ${ }^{113}$

Like other ancient legal institutions, cessio bonorum was revived in the later Middle Ages, as commercial life and knowledge of Roman law grew. But

109. UDEMANS, supra note 46 , at $10[\mathrm{v}]-11[\mathrm{r}]$ :

maer vooral met bancquerouterie, dat is/ wanneer sy vele capitalen hebben ghelicht tot haren lastel of dat vele eerlijcke luyden haer/ op haer woordt, of schrift, maer insonderheyt op wissel gecrediteert hebben/ datse daer na een onbeschaemt aensicht aentrecken/ sluyten haer selven binnen de mueren van haer huys/ ende laten de goede luyden na'kijcken/ segghende rondt uyt/ datter niet ten besten en is, al ist datse dickwils korts te voren groote parthyen hebben in-gekocht/ diemen niet en weet/ waer sy gevaren zijn. Dit is eene grouwelijcke specie van dieverie....

Udemans went on to cite the Edict of Charles V, see infra noie 110.

110. Cessio bonorum, it should be noted, was not the only important issue in the moral world of insolvency. Also of significance was the (to date much more widely studied) problem of the fugitive merchant. This was a problem (among others) treated in the Edict of Charles V of the 4th October, 1540, which had force in Holland. See 1 GroOT PLACAET-BOEK 311-22 (Cornelis Cau ed., s'Gravenhage, By de Weduwe, ende Erfgenamen van wylen Hillebrandt Iacobsz. van Wouw 1658). On the problem of fugitive merchants, see, e.g., Vito Piergiovanni, The Itinerant Merchant and the Fugitive Merchant in the Middle Ages, in OF STRANGERS AND FOREIGNERS (LATE ANTIQUITY-MIDDLE AGES) 81 (Laurent Mayali \& Maria Mart eds., 1993).

111. For the uncertainty as to whether this legislation is owed to Caesar or to Augustus, see MAX KASER, DAS RÖMISCHE ZIVILPROZESSRECHT 316 (1966), with citations to further literature.

112. For Caesar, see DANIEL Wegner, DE BANCCIRUPTORIBUS DiSSERTATIO 180 (Franeker, Idzardus Alberti 1650). For Augustus, see SICHARNIUS IN VHEVESINU, VON DER BONORUM CESSION, UND BANCKEROTT/ DISCURSUS JURIDICO-POLITICUS. AUS DEN RECHTSBÜCHERN AUFFS KÜRZTE ZUSAMMEN GEFASSET/ ALLEN KAUFF- GEWERBS- UND HANDELSLEUTEN ZUR NACHRICHTUNG VERDEUTSCHT/ UND IN ACHT CAPITTEL DISTRIBUIRET. GEDRUCKT IM JAHR/ IST NIT BANCKEROTT ITZO GAR ZV GEMEIN VVORDEN? 3-4 (N.p., n.d. [dated by a seventeenth-century hand as 1619 in the Bayerische Staatsbibliothek, Munich]).

113. See generally the description in KASER, supra note 111, at 316-17. 
although cessio bonorum was revived in the Middle Ages, it was revived in a strikingly circumscribed form. Medieval legal practice permitted cessio bonorum, which had unimpeachable authority as a Roman institution, but insisted on adding to it heavy sanctions of dishonor. As early-sixteenth-century canon lawyers explained it, a debtor insolvent through no fault of his own could receive a full discharge by declaring cessio-but only if he performed his cessio, as the canonists put it, vituperose, "amidst shame." 114

What did "amidst shame" mean? What it involved, in Italy and southern France, were some memorable procedures, belonging to a species of law that is very nearly forgotten in the United States today: shame sanctions. Insolvency, in premodern Europe (as in the United States, at least until the passage of the Bankruptcy Reform Act of 1978) was surrounded with shame; and the law of premodern bankruptcy involved enhancing that shame through a wide range of little-studied public rituals.

In particular, many of these rituals centered on what was called "The Rock of Shame." The debtor was commonly brought to a public piazza, always the scene of spectacles, feuds, humiliations, and the like; or before a session of the city council or court. There:

The custom has grown up, in parts of Italy, that the insolvent who wishes to declare a cessio bonorum must go naked in a public and notorious place. There he strikes his backside three times against a rock or column, crying out, I DECLARE BANKRUPTCY. ${ }^{115}$

Northern Italian cities had a special rock, prominently located, against which bankrupt debtors were obliged to bang their buttocks before a jeering crowd, after first displaying themselves in some state of undress, or simply nude. In the city of Padua, for example, the rock of shame stood in the middle of the vast Paduan Palace of Justice, where it can still be visited. ${ }^{116}$ (The Paduan

114. Matteo Bruno tractatus Matthaei Bruni arimineni de Cessione Bonoru 115[v] (Venice, 1561) [hereinafter BRUNo, TRACTATUS (VENICE)]; MATTEO BRUNo, TRACTATUS MATTHAEI BRUNI ARIMINENI DE CESSIONE BONORU 10[v]-11[r] (Venice, Apud Haeredes Aloysij Valuassoris, \& Ioannem Dominicum Michaelem 2d ed. 1575) ("Unless he has ceded his goods amidst shame, according to the statutory form, banging his buttocks on a rock . ... ."); see also GUIDO PAPA, DECISIONES GUIDONIS PAPAE, IURISCONSULTI GRATIONOPOLITANI 319 (Lyon, Sumptibus Ioannis de Gabiano 1613); 1 FranCisCo SAlgado DE SOMOZA, LABYRINTHUS CREDITORUM CONCURRENTIUM AD LITEM PER DEBITOREM COMMUNEM INTER ILLOS CAUSATAM 558 (Venice, Apud Turrinum 1653) (standard authority of period).

There was a common requirement that debtors be insolvent through no fault of their own, which naturally raised some hairy doctrinal difficulties. See, e.g., SCACCIA, supra note 80, at 480 (proposing simply to put burden of proof in this regard on debtor); STRACCA, supra note 81, at 345-47; WEGNER, supra note 112 , at 38-51 (discussing determination of "fault" of debtors).

115. BRUNO, TRACTATUS (VENICE), supra note 114, at 115[v].

116. See Statuti del Comune di Padova, dal Secolo XII all'Anno 1285, at 7 n.(c) (Padova, Giugno 1873) [hereinafter STATUTI DEL COMUNE DI PADOVA] (describing rock of shame); id. at 179 (giving relevant statute). See also the discussion of this statute in BRUNO, TRACTATUS (VENICE), supra note 114, at 116[r]. Clearly enough, these practices call for deeper anthropological interpretation that would be out of place in this Article. 
Palace of Justice, incidentally, was decorated with now-lost frescoes by Giotto; ${ }^{117}$ it is startling to imagine these barbaric procedures taking place under yards of painting by the most glorious and moving of Western artists.) After this frightening and humiliating ceremony, Paduan bankrupts, like bankrupts in some other parts of Italy, would be sent into banishment. ${ }^{118}$ French cities, for their part, sometimes had other medieval shaming customs, including most famously the wearing of the bonnet vert, the green cap. ${ }^{119}$ As for the English, they rejected cessio bonorum entirely; Blackstone still viewed cessio bonorum as a pernicious Roman institution, "fertile of perjury, injustice and absurdity." 120 Nevertheless, it is worth mentioning the parallel shame sanctions imposed there; English bankrupts faced not only imprisonment, but also in some cases the shame sanctions of pillory and the loss of an ear. ${ }^{121}$

This lurid tradition of shaming was embraced and rationalized by Christian jurists. Christian rationalization of the shame sanctions took two forms. First, jurists gave shame sanctions a basis in the logic of justice by granting, not only immunity from imprisonment, but also a full discharge to debtors who had undergone "shame."122 Second, they fit bankruptcy thinking into the same tradition of Pauline moral philosophy that underlay just-price restrictions: To take advantage of cessio bonorum, they reasoned, was, once again, to "overreach," to violate the demands of brotherly charity imposed by

117. See G. Bozzolato, Il Palazzo della Ragione a Padova, in Il Palazzo DElla Ragione a PAdova DALle PITTURE di GioTto AGLI AFFreSCHI DEL '400, at 42, 42-46 (1992).

118. See STATUTI DEL COMUNE DI PADOVA, supra note 116, at 179. For a general account of these statutes in Italy, see 6, pt. 2 ANTONIO PERTILE, STORIA DEL DIRITTO ITALIANo 384-88 (1902); on banishment, see further HANS PLANITZ, DAS SCHULDBANN IN ITALIEN 134 (Zeitschrift der Savigny-Stiftung für Rechtsgeschichte, Germanistische Abteilung No. 52, 1932). See also Piergiovanni, supra note 110, at 81-96 (discussing similar treatment of fugitive insolvents). Cessio bonorum is intentionally omitted from the treatment of UMBERTO SANTARELLI, PER LA STORIA DEL FALLIMENTO NELLE LEGISLAZIONI ITALIANE DELL'ETẢ INTERMEDIA (1964). See id. at 3-4. Nevertheless, Santarelli inevitably touches on the topic. See, e.g., id. at $29-30$.

119. See Jaceues Savary, Le Parfait Négociant 311-12 (Paris, J. Guignard fils 1675), which describes this practice, under which the creditors bought a green cap for their insolvent debtor, and policed his wearing of it. See also the following discussion in Savary, which details the elimination of this medieval custom by an ordonnance of 1629 , which substituted the public posting of the names of those who had performed a cessio bonorum, $i d$. On the wearing of the green cap, see also, e.g., GABRIEL BOUNIN, TRAITE SUR LES CESSIONS ET BANQUEROUTTES 75-76 (Paris, Chez Pierre Chevillot 1586), defending this French practice as more humane than the common Italian practice; and more generally the sketch in CLAUDE DUPOUY, Le DRoIT DES FAILlites EN FRANCE AVANT LE CODE DE COMMERCE 14-15 (1960), which also refers to some other French customs; and the survey in HILAIRE, supra note 82, at 306-24. I have not seen Guillon, Essai Historique sur la législation française des faillites et banqueroutes avant 1673 (1904) (unpublished dissertation, University of Rennes). The reason for the elimination of the customary sanctions in 1629 is not entirely clear to me; but it should presumably be seen as an aspect of the assertion of centralized power over local traditions in France, rather than as a reevaluation of insolvency.

120. 2 William Blackstone, CommentaRies *472.

121. Louis E. Levinthal, The Early History of English Bankruptcy, 67 U. PA. L. REV. 1, 17 (1919). These shame sanctions were introduced by the Act of 21 Jam. 1, ch.19 (1623) (Eng.), and should be viewed in the context of a general European effort-outside Holland-to limit bankruptcy in the early seventeenth century.

122. See supra text accompanying note 114 . 
the Christian faith, and in particular by 1 Thessalonians $4,6 .{ }^{123}$ European bankruptcy law thus displayed precisely the same pattern as did the medieval law of overreaching. Within a world of interpenetrating secular and Christian norms, the authority of a liberal Roman rule was acknowledged; but its actual use was limited by severe restrictions founded in Christian "charity," endorsed and justified by the canon lawyers. ${ }^{124}$

In most parts of Europe, moreover, those restrictions grew in scope and force during the sixteenth and seventeenth centuries. In France and Italy, as Walter Pakter has observed, bankruptcy was "progressively criminalized." 125 The same was true of England and the Holy Roman Empire, which set about vigorously penalizing "fraudulent" insolvency. ${ }^{126}$ Particularly in the early seventeenth century, bankruptcy was everywhere perceived as a growing, and dangerously immoral, practice, and was sanctioned.

Thus the early-modern French kings made ever-intensifying efforts to guarantee that merchants would not try to escape the shame associated with their act. Particularly interesting is a series of royal ordonnances, from 1490 to 1673 , that forbade the practice, permissible under Roman law, ${ }^{127}$ of declaring bankruptcy through an attorney. The idea that one could declare bankruptcy through an attorney ran counter to the great common European policy of inflicting personal humiliation directly upon the debtor himself. Declaration per attorney, as a leading French author thus explained, simply spared the debtor too much shame. Accordingly, French law required bankrupts to appear before a judge in person, and "bare-headed and with their clothing hanging open [to expose their naked bodies], to mark and augment their infamy." 128 This remained thoroughly in the old Christian tradition-so much

123. See, e.g., Daniel SAUTER, Praxis BANCCAE-RUPTORUM huIUS SECUli; QUaE 1. SECUNDUM FALLACES ACTIONES DEPINGITUR: 2. SECUNDUM MALA ADIUNCTA EXPENDITUR: 3. SECUNDUM POENAS IN EAM SANCITAS, AESTIMATUR: 4. SECUNDUM CHARITATEM EMENDATUR 11 (Leiden, Godefridus Basson 1615) (describing bankruptcy abuses as a form of circumvenire, "overreaching").

124. For the classic reasoning applied to bankruptcy, see, e.g., SCACCIA, supra note 80 , at 342 .

125. Walter Pakter, The Origins of Bankruptcy in Medieval Canon and Roman Law, in PROCEEDINGS of THE Seventh International Congress of Medieval Canon LaW 485, 505 (Peter Linehan ed., 1988).

126. For the common history of English and continental bankruptcy legislation, see Stefan A. Riesenfeld, Bankruptcy and Insolvency, in 15 THE NEW ENCYCLOPEDIA BRITANNICA: MACROPEDIA 370 (15th ed. 1992).

127. D. $42,3,9$.

128. See SALGADO, supra note 114, at 6; SAVARY, supra note 119, at 308-09 (quoting and discussing Ordonnance de Lyon de Louis XII, June 1510, art. 70). For the French versus the Italian practice, see the annotations in PAPA, supra note 114, at 319 . French procedures also required other measures, including the posting of the names of bankrupts in a public place and the public display of their (clothed) persons on a market day, with the reading of the charges against them by an officer, measures whose "infaming" character is discussed by SAVARY, supra note 119, at 309-10. For the French practice, see further PHILIPPE GODDING, LE DROIT PRIVE DANS LES PAYS-BAS MÉRIDIONAUX DU 12E AU 18E SIĖCLE 519 (1987), and the

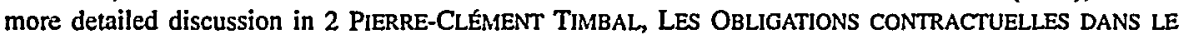
DROIT FRANÇAIS DES XIIIE ET XIVE SIÈCLES D'APRES LA JURISPRUDENCE DU PARLEMENT 228-39 (1977). While cessio bonorum required royal letters in France, those letters were routinely granted by the end of the Middle Ages. See id. at 228 n.565. 
so that a late-sixteenth-century French author took it as natural to begin his treatise on bankruptcy with a disquisition on Christian charity. ${ }^{129}$

Even the seventeenth-century authors most favorably disposed toward the rights of insolvents under Roman law had no choice but to detail the shame sanctions they faced. Thus, a German pamphleteer of 1619 did his best to plead the cause of the deserving but unfortunate merchant debtor. His pamphlet, intended to bring the content of the learned legal literature to German-speaking "merchants, craftsmen, and businessmen," began by painting a vivid moral picture of the world of bankruptcy in the early seventeenth century. The author, who was named Sicharnius, had surely himself been insolvent at some time:

When merchants return home from the fairs and annual markets in great commercial cities, dear benevolent reader, they are commonly accustomed to bring all sorts of reports and bits of news with them, among which the first is almost always this: Once again, some debtor has gone insolvent and declared bankruptcy. Once word of this makes the rounds and becomes known, the average man bursts out with imprudent, violent and angry words. He storms, curses, blasphemes, says scandalous and contemptuous things about debtors, denouncing them as rogues, thieves, and men without honor, making no distinction between those who have been ruined through nonsurreptitious and unforeseeable accidents (as is declared by his Majesty Emperor Charles V in his Administrative Ordinance of 1548, under the heading "Of Ruined Merchants") and those who have suffered losses and fallen into poverty through risky, intentional, and deceptive behavior, living disorderly lives and enjoying excessive luxury.

But this sort of contemptuous and insulting attitude does injustice to many honorable and upright merchants and businessmen, who, as a consequence of accidental misfortune, have been forced and compelled against their will to perform a cessio bonorum, that is: To abandon and cede their goods to their creditors.

So it is that the author of this discourse wishes, first of all, to confront these railers and foul-mouthed folk, confound their unjust judgments, and as far as possible impose silence upon them. ${ }^{130}$

Cessio bonorum, he wished to inform his readers, was a glorious Roman institution, introduced by no less a figure than Augustus. ${ }^{131}$ This champion of cessio bonorum presented Roman doctrine as favorably as he could, endorsing, among other rights, the right to declare bankruptcy by attorney. ${ }^{132}$

129. See Bounin, supra note 119 , at $4-5$.

130. SiCHARNIUS, supra note 112 , at $3-4$.

131. Id. at 8. For more on the importance of Augustus in the legal thought of the seventeenth century, see WHITMAN, supra note 2 , at $56-60$, and the literature cited therein.

132. SICARNIUS, supra note 112 , at 31 . 
But the reality was that even "honest" German debtors who sought to take advantage of this glorious Roman right faced unspeakably grim debtors' prisons. ${ }^{133}$ Nor could Sicharnius avoid warning his readers that they faced ugly shame sanctions if they declared cessio bonorum in other countries:

Since ancient times, bankrupts and persons declaring cessio bonorum have been obliged to use particular words and perform ceremonies .... .

In some places, they must let their clothing hang open and say, "I DECLARE BANKRUPTCY'. ... .

The Amalthasani banged their heads against the earth, combed them with a comb, and shouted "I DECLARE BANKRUPTCY."

Among the Boeotians, the debtor sat in the marketplace, holding a basket in his teeth, or else letting a basket drop over him, while the populace stood around, as is evidenced by the example of Mnesiarchus, the father of the poet Euripides, to whom this happened. It is said that in some parts of Italy it is the custom that anyone who declares bankruptcy must roam the streets naked, then bang his can [sein Gefäß] three times against a stone or a column, and scream "I DECLARE BANKRUPTCY."

As Cino da Pistoia writes ... in Rome the debtor must climb up on a marble lion in the Capitol, and bang his rear end against it .... ${ }^{134}$

In virtually every part of early-modern Europe, cessio bonorum was either unavailable, or available only to those willing to brave daunting public shame.

Virtually every part-except the Lowlands. For it is a remarkable, but as yet unremarked, fact that these traditional, and brutal, shame sanctions died away in the commercializing Lowlands. Just as the Roman law of overreaching circulated unimpeded in Dutch vernacular literature, the Roman law of debtor protection through cessio bonorum came into unimpeded use.

This seems to have begun in the Lowlands commercial center whose rise to prominence preceded that of Amsterdam: Antwerp. ${ }^{135}$ Already in the mid-sixteenth century, vernacular Flemish authors contrasted the cessio

133. See the pitiful description in CHRISTOPH BESOLD, THESAURUS PRACTICUS 728 (Tübingen, Apud Philibertum Brunnium 1629) (quoting EBERHARD SPECKHAN, QUAESTIONUM \& DECISIONUM IURIS Caesarei, Pontificil, Statutaril \& Consuetudinaril Centuria Prima Miscellanea 105 (Wittenberg, Clement Berger 1620)). In Germany as in England, inmates in debtors' prisons received no food; and according to these descriptions, passersby in commercial cities in Germany were used to hearing inmates cry wretchedly and beg for food. Sicharnius tried to plead against these practices. See SichARNIUS, supra note 112 , at 35-36. But the truth was that cessio bonorum had in effect generally not been received in

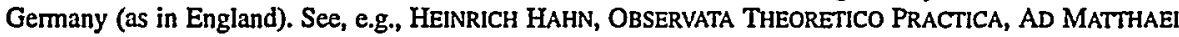
WESENBECII IN L. LIBROS DIGESTORUM COMMENTARIOS, \& IN HOC EDITAS REINHARDI BACHOVII NOTAS \& ANIMAADVERSIONES 355-56 (Heimstedt, Typis et Sumptibus Henningi Mulleri 1668), which, to be sure, cited much Roman legal doctrine, but which noted simply that the Roman rules were not in use under Saxon law.

134. SiCHARNIUS, supra note 112 , at 33 .

135. For the common legal heritage of the Lowlands generally-and of Burgundy-see the remarks of FEENSTRA, supra note 98 , at 3-4. 
bonorum of their own country with that of nearby France. Lowlands law on cessio bonorum was in some ways quite close to French law. ${ }^{136} \mathrm{But}$ in France, as authors such as Philips Wielant ${ }^{137}$ and Joost Damhouder ${ }^{138}$ noted, cessio bonorum could not be done by attorney, and it had to be performed in a "humiliating" way. Their own Flemish law, by contrast, was different, comprising largely the unadorned rules of Roman law; ${ }^{139}$ Damhouder even observed that debtors of his day had begun to glory in obtaining a cessio. ${ }^{140}$

When the center of gravity of commerce moved to Calvinist Amsterdam, this Flemish law (like all of the customary commercial law of Antwerp) continued to govern. ${ }^{141}$ And indeed, like their Flemish predecessors, Dutch authors were aware that something had changed in the traditional system of shame. This is a development we can detect both in the vernacular legal literature and in the moralizing literature. To begin with the vernacular legal literature: Strikingly few of the vernacular legal authors even mention shame sanctions. But I have found at least one author who commented directly on the demise of Italian-style shame sanctions in his country. Simon van Leeuwen, a learned text writer with strong antiquarian tastes and no great sympathy for insolvents, collected and described shaming statutes in his general introduction to Dutch law; the first, 1652 edition of his book described a typical shaming statute, dating to 1501 , from van Leeuwen's hometown ${ }^{142}$ of Leiden. But van Leeuwen felt obliged to note that this hometown statute had fallen into disuse:

According to statute in some cities, [cessio bonorum] has no place; or else those that want the benefit of a cessio must expose themselves in their underclothes before the city hall for an hour at midday, for several days, at a certain raised spot called "the jaws" [i.e., the stocks]. See, for Leiden, the Ordonnance of July 30, 1501, and for

136. In particular, in the Lowlands as in France, see supra note 128 and accompanying text, the right to perform a cessio had to be sought, technically, as a benefit from the court. See, e.g., Grotius, supra note 107, at 509, observing that this distinguished Dutch law from classical Roman law.

137. Phil. IPS Wielant, PRACTIJKe Civile 83 (E.I. Strubbe ed., 1968) (1573).

138. IOOST DE DAMHOUdER VAN BRUGGE, PRACTYCKE IN CIVILE SAECKEN, SEER NUT/ PROFITELIJCK ENDE NODIGH ALLEN SCHOUTEN, BORGHEMEESTEREN, MAGHISTRATEN ENDE ANDERE RECHTEREN 154 (s'Graven-Hage, By de Weduwe, ende Erfgenamen van wijlen Hillebrant Iacobssz. van Wouw 1626).

139. Though still possibly carrying the disability, in the mid-sixteenth century, to serve in public office or as member of a guild, and with some fluctuations in customary law. See GoDDING, supra note 128, at 519. Nevertheless, as Godding makes clear, the liberalization I trace had already largely taken place in Flemish law by the mid-sixteenth century.

140. For Damhouder's recognition that there had been a liberalization in his day, and that some debtors even gloried in having performed a cessio bonorum, see id.

141. For the applicability of the Custom of Antwerp, see J. Denuce, Archives commerciales privées: le fonde des faillites à Anvers, in 4 ANNALES D'HISTOIRE ÉCONOMIQUE ET SOCIALE 372 (1932); LICHTENAUER, GESCHIEDENIS, supra note 37, at 9-10 (for general applicability of Custom of Antwerp); id. at 11, 194 (for applicability in law of bankruptcy).

142. See RENE DEKKERS, BIBLIOTHECA BELGICA JURIDICA: EEN BIO-BIBLIOGRAPHISCH OVERZICHT DER RECHTGELEERDHEID IN DE NEDERLANDEN VAN DE VROEGSTE TIJDEN AF TOT 1800, at 98 (1951) (biographical data on van Leeuwen). 
Rotterdam, the Ordonnance of $1519 . \ldots$ But to my knowledge this never occurs within the city of Leiden .... ${ }^{143}$

Van Leeuwen added that there was no longer any particular shame involved in cessio bonorum. The "public scandal" was gone from bankruptcy in Leiden. ${ }^{144}$ Other authors, too, spoke (if only obliquely) of the decline of shame rituals. ${ }^{145}$

143. Simon van Leeuwen, Manier van Procederen in Civile en Criminelle SaAken 104 (Leiden/Rotterdam, 1666):

Dog heeft het selve benefitie van cessie, dat is, boedel-affstand, volgens Handvest van sommige Steden geen plaats, of moeten die gene die het selve versoeken, eenige dagen des middags, een uyr lang voor het Stadthuys, op sekre verheven plaats, dat men een Kaak nomt, in sijn onderste klederen ten toon staan. als tot Leyden volgens Octroy van den 30. Julij 1501, ende tot Rotterdam volgens Octroy van den Jare 1519. [Omitted passage quoted in next footnote]... Dog is t'selve binnen de Stad van Leyden, mijns wetens, noyt geschied ....

144. Id.:

van den Jare 1519. in welken geval sommige willen, dat, met dat daarom opentlijk schandaal werd geleden, die gene die sulx doet, van de gehele schult soude bevrijd zijn. arg. l. 13. §. 7. ff. de his qui not. infamia. l. 4. C. ex quib. caus. infam. irrogat. Dog is 't selve binnen de Stad van Leyden, mijns wetens, noyt geschied, maar moeten aldaar die gene die om schuld gevangen geset werden, so lang blijven sitten, tot dat het de Schduldneyssers selfs moede werden, het welk men noemt, door de tralie eeten.

in which cases, there are some who would argue that, seeing that there is thereby a public scandal, anybody who performs such rituals is discharged from all of his debts . . . But to my knowledge this never occurs within the city of Leiden. Instead, those who are captured by their creditors must remain imprisoned until the creditors get tired of holding them, which is called "eating through the bars."

Van Leeuwen's eagerness to show that there was no longer any shameful "public scandal" in Leiden reflected, of course, his hostility to insolvents: He wanted to deny them the traditional canon-law discharge granted upon the performance of cessio vituperose. See supra note 114 and accompanying text. Nevertheless, it remains fascinating evidence of the state of public perceptions in a major Dutch city.

There is something of a mystery in van Leeuwen's assertion that debtors were imprisoned in Leiden. This was a sanction against which cessio bonorum should have immunized them. Moreover, according to other sources, citizens of Leiden were immune from imprisonment. Until the late sixteenth century, they had been subject to imprisonment after a ceremony stripping them of citizenship. That ceremony had, however, died away sometime in the 1570s. See J.J. ORLERS, BESCHRIJVINGE DER STAD LEYDEN 21-23 (Leyden, Haestens et al. 1614). Wegner, writing in 1650 in a vein very hostile to debtors, and with a greedy interest in listing all the sanctions he could discover, knew of no imprisonment of debtors in Leiden at that time. See WEGNER, supra note 112, at 146-47 (erroneously dating end of imprisonment in Leiden to 1614 on the basis of his misreading of the 1641 edition of Orlers. See J.J. ORLERS, BESCHRIJVINGE DER STAD LEYDEN 34-36 (Leyden, Abraham Commelijn 1641)). I assume that van Leeuwen's hostility to debtors led him to describe here, in a typical instance of tendentious antiquarianism, an irrelevant or obsolete imprisonment practice. (The phrase "eating through the bars" reflects, presumably, a memory of the presence of starving inmates in the debtors' prisons of the past. Cf. supra note 133.)

Such distortion on account of hostility to debtors characterizes, in fact, other aspects of van Leeuwen's problematic corpus, and marks him out as typical of the learned jurists' hostility to commercial values. See infra note 166. The passage quoted tracks material that van Leeuwen had presented in his substantive introduction to Roman-Dutch law. See SIMON VAN LEEUWEN, PARATITLA JURIS NOVISSIMI, DAT IS, EEN KORT BEGRIP VAN HET ROOMS-HOLLANDS-RECHT 412 (Leyden, P. Leffen 2d ed. 1656) (including reference to statute of Rotterdam); SIMON VAN LEEUWEN, PARATITLA JURIS NOVISSIMI, DAT IS, EEN KORT BEGRIP VAN HET ROOMS-HOLLANDS-RECHT 346 (Leyden, P. Leffen 1652) (including only reference to statute of Leiden). In his introduction to substantive law, however, van Leeuwen did not bother to mention that the statute of Leiden had fallen into desuetude! Only in his guide to practice did he mention that fact. Modern readers can easily be misled by an antiquarian tendency of this sort in their sources.

145. See GERARD VAN WASSENAER, PRACTYK JUDICIEEL OFTE INSTRUCTIE OP DE FORME VAN, 
The silence of other authors confirms what van Leeuwen says expressly. For most Dutch vernacular legal authors, there was simply, strikingly, nothing to say on the topic of shame. On the contrary: The Dutch vernacular legal texts, here once again, merely presented, in a coolly unmoralizing way, the Roman rules. We may start with an example from Zutphen. (The topic here involves a technical doctrine called "infamy," which I describe in the margin.):

[Cessio Bonorum] I. The question is whether a person who declares a cessio bonorum is subject to infamy as a result. I answer No. Papon. lib. 10. tit. 10. de cess. bon. arrest. 5. Christin. ad 11. Mechlin. tit. 21. art. 2. nu. 2. \& 3. Math. in not. ad Guid. Pap. q. 343. Brun. de Cess. bonor. q. 6. princip. num. 3. 4.

By contrast with jurists elsewhere, moreover, Zutphen saw no obstacle to repeated filings:

[Cessio Bonorum] III. It is asked whether a person who has once declared cessio bonorum, and who wishes to declare cessio bonorum once again afterwards, is permitted to do so. I answer Yes. Pyrrh. Maur. in tract. de Fidejuss. 1. part. princip. 3. sect. praelud. cap. 2. alias 11. nu. 6. Hering. de Fideiuss. cap. 5. num. 127. \& 128. ${ }^{146}$

Not a word, here, of the shame sanctions that our contemporary German pamphleteer felt obliged to describe. The same is true, to take another example, of Grotius's Inleiding. In his treatment, Grotius went into some detail on the mechanics involved in the application for cessio, and into some detail on the mechanics preventing debtors from concealing assets. He uttered not a word, however, about ritual humiliation of any kind. ${ }^{147}$

PROCEDEREN 330 (Utrecht, Dirck van Ackersdÿck 1660) (describing French practice of requiring debtors to appear bare-headed and with their clothing hanging open in court but noting " $t$ 'welk nochtans niet altijd en over al so word geobserveert" ["which is however not observed always and everywhere"]). Wassenaer is, however, perhaps not a good witness to Dutch practice, since he conceived his book as covering both Dutch and French law. See, e.g., id. at 2.

146. ZUTPHEN, supra note 93 , at 119:

I. De vrage is/ of den ghene die cessie van sijne goederen ghedaen heeft/ daer door is infaem? Ick antwoorde Neen. Papon. lib. 10. tit. 10. de cess. bon. arrest. 5. Christin. ad 11. Mechlin. tit. 21. art. 2. nu. 2. \& 3. Math. in not. ad Guid. Pap. q. 343. Brun. de Cess. bonor. q. 6. princip. num. 3. 4 .

* * *

III. Wordt gevraeght/ of den ghene die eens cessie van sijne goederen ghedaen heeft/ indien hy naderhandt wederom doen wil cessie van sijne goederen/moet gheadmiteert worden? Ick antwoorde Ja. Pyrrh. Maur, in tract. de Fidejuss. 1. part. princip. 3. sect. praelud. cap. 2. alias 11. nu. 6. Hering. de Fideiuss. cap. 5. num. 127. \& 128.

Under Roman law, cessio bonorum did not bring with it legal infamia, a kind of formal stigmatization which carried various disabilities. For more on infamia generally, see, e.g., CrooK, supra note 58, at 83-85. Whether or not cessio bonorum was de facto infaming in classical law is disputed. See LuCIEN GUENOUN, LA CESSIO BONORUM 67-69 (1920); KASER, supra note 111, at 317; Pakter, supra note 125, at 487.

147. See Grotius, supra note 107 , at $509-11$. 
At a time when French or Italian debtors faced fearsome shame sanctions, and German and English ones faced hellish prisons, this Dutch practice was stunningly liberal, a long step on the road toward modern bankruptcy. Evidence seems to show that Dutch merchants took advantage of this liberal rule, too, with rates of the declaration of cessio noticeably high in the seventeenth century. ${ }^{148}$

How did all this sit with the authors of the moralizing literature? The decline of shame sanctions was quite unacceptable to some Dutch moralists. At least one author went into paroxysms of denunciation, developing exotic humanist lists of the horrors properly visited upon bankrupts elsewhere, but spared them in Holland. ${ }^{149}$ (The Calvinist churches, too, made efforts to curb cessio. ${ }^{150}$ ) But it is a striking fact that not even the Calvinist moralists were unanimous. Udemans, horrified though he was by the behavior of bankrupts, was not horrified by the things that horrified moralists elsewhere in Europe, for Udemans saw no evil in cessio bonorum as such. On the contrary. Udemans's principal piece of moral advice to merchants was to submit peacefully to cessio; and his main lament was about the disappearance of traditional Dutch shame sanctions imposed, not for cessio as such, but for the concealment of assets:

There are many merchants who, when they fall into difficulties, try to help themselves by means of tricks: Before they make an ostensible cessio bonorum, they conceal all the assets that they can; before they pay what they owe, they try to call in as many debts as they can, for they think, "I cannot go out naked into the world; I cannot live from the wind; I cannot eat my hands or my fingers. Where shall I abide with my poor wife and children? What I conceal now will be of help to me, and it cannot hurt my creditors very much, \&c." But all these thoughts come from Satan, from the old serpent, from the great red dragon, who is a liar, and a father of lies, and a seducer of the whole world. Apoc. 12, 9. ${ }^{151}$

148. LICHTENAUER, GESCHIEDENIS, supra note 37, at 118, 196.

149. See SAUTER, supra note 123, at 49-51. This book was rapidly translated into German and later into English, languages in which it presumably could find a more favorably inclined audience. Sauterius also produced an entire monograph devoted to this topic in comparative law. See DANIEL SAUTER, MASTIX FALLITORUM (Leiden, Ex Officina Iacobi Marci 1619). On this literature, see generally LicHTENAUER, GESCHIEDENIS, supra note 37 , at 117-20.

150. Beins, supra note 45, at 133-34. The churches imposed their mildest form of excommunication; but Beins's research showed high rates of bankruptcy by congregation members. For the medieval imposition of excommunication for nonpayment of debt, see VINER, supra note 12, at 47 , and the literature cited there.

151. UdEMANS, supra note 46 , at $14[\mathrm{r}]$ :

So zijnder oock vele Coopluyden, als sy komen te verbysteren/ die haerselven met sulcke treken soecken te behelpen: eer sy quamsuys cessie doen, soo versteken sy al datse konnen/ eer sy uittinghe doen, soo doen sy inninge, want sy dencken/ick en kan daer niet naeckt uytgaen, ick en kan vanden windt niet leven, ick en kan handen noch vingheren eten: waer sal ick blyven met myne arme vrouwe ende kinderen? dat ick verberghe, dat kan my helpen, ende het en kan de crediteuren niet vele schaden, \&c. Maer alle dese gedachten komen 
If insolvency came, merchants were simply, and honestly, to declare a cessio. Above all, they were not to conceal assets. Concealment of assets had traditionally been penalized, Udemans observed, through the awesome shame sanction of branding. Udemans noted that the mid-sixteenth-century Edict that governed concealment of assets, along with other acts of "fugitive" bankrupts, harsh though it was, did not impose such bloody penalties. But Pauline principles remained. Merchants, he said, should learn the lesson taught by the traditional customs:

Our forefathers, the upright Netherlanders, regarded any kind of filthy acts of bankruptcy [such as concealment of assets] as such a dishonorable and enormous crime, that not only the bankrupts themselves, but anybody who gave them aid and comfort, is to be punished and branded, so that everyone should learn to guard against doing that sort of thing. Even though the Imperial laws are no longer applied with such severity, nevertheless, divine law remains in full force. 1 Thess. 4, 6: No man must overreach his brother in business transactions, or invade his rights, because, as we told you and witnessed to you before, the Lord punishes all such offenses. ${ }^{152}$

If the Dutch law on overreaching showed a movement from regulation of price to regulation of quality, the Dutch law of bankruptcy, at least as reflected in passages like this, showed a movement too: a movement from penalizing insolvency to penalizing asset concealment-or, in common law terms, from penalizing bankruptcy to penalizing acts of bankruptcy.

This was, again, a great change, a profound change. ${ }^{153}$ It can hardly be overemphasized how different was the moral world in which Udemans moved from the world of any moralist or lawyer of any other European nationality. Cessio, anywhere else in Europe, was a reprehensible act. To Udemans, it had become, for insolvents, the only honorable act. Bankruptcy was, perhaps more than any other institution, the realm in which Roman law had begun to provide moral authority for something very alien, and something that elsewhere was

vanden Sathan, van die oude slanghe, van dien grooten rooden draeck, die een leughenaer is/ ende een vader der leughenen, ende die de geheele wereldt verleydt. Apoc. 12.9.

152. Id. at $11[\mathrm{v}]$, waming merchants to consider:

voor wat een oneerlijcken ende enormen crijm dat de vuyle bancquerouterie oyt ende oyt by onse Voor-ouders, de oprechte Nederlanders, ghegouden is/te weten/ dat niet alleene de bancqueroutiers selve, maer oock die daer toe raedt en daet geven/ daer door in het lyden komen/ ende ghebrandt-markt worden/ op dat een yder hemselven daer voor soude leeren wachten. Want al ist dat de Keyserlijcke Wetten nu soo strengelijck niet en worden gheexecuteert/ so blijft niet-te-min die Goddelijcke Wet in hare volle kracht. 1 Thess. 4. vers. 6. Dat niemant synen Broeder en verdrucke, noch bedrieghe, want Godt is een wreker over allen desen, gelijk wy u.l. te voren gheseyt en betuycht hebben.

153. SCHAMA, supra note 40 , at 330 , and Beins, supra note 45 , at 128 , observe correctly that Udemans counseled merchants to avoid excessively risky ventures. That indeed was Udemans's principal prescription for avoiding insolvency, and it certainly reflects a less than fully developed commercial morality. But the fact remains that Udemans's general treatment of risk and insolvency set him sharply apart from non-Dutch Christian authors. 
considered profoundly objectionable. A satirical couplet of the day, from a rhyme entitled The Merchant, captured the issue:

And even if he should go bust, leaving his bills unpaid-well then, It's off to file a quick cessio. Presto!, an honorable man again. ${ }^{154}$

"Weer een man met eeren"-once more a man of honor. This was unimaginable, and wholly unacceptable, in any other part of the European world.

The pattern, in the cases of both just price and cessio bonorum, is clear enough: Roman law coolly permitted commercial behavior that the traditions of Christian theology deemed profoundly objectionable; and the texts, and benefits, of Roman law became more easily accessible in seventeenth-century Holland, at a time when they were becoming, if anything, less accessible elsewhere. A similar tale could be told, moreover, in the case of a third leading aspect of commercial life, the lending of money at interest. With regard to money lending, a Roman rule was, once again, invoked, with success, to justify departure from a strict Christian tradition of condemnation founded in Paul's famous passage at 1 Thessalonians $4,6 .{ }^{155}$

But what should we say that that pattern proves?

First of all, it obviously does not prove that Roman law was the direct "cause" of the rise of a commercial order in Holland. Roman law spread into all parts of Europe. What set Holland apart from its sister European nations was not that the Dutch were alone in having knowledge of Roman law, but that they were alone in tolerating its relatively unrestricted use. Other parts of Europe, to employ Brunner's famous metaphor, "resisted" the "infection" of Roman law. In other parts of Europe (and in the Middle Ages), the authority of cessio bonorum was accepted; but the practice of cessio bonorum was resisted through the imposition of shame sanctions. In other parts of Europe (and in the Middle Ages), the authority of the Roman rules on overreaching was accepted; but the use of those rules was resisted through the supervening rules of the forum internum. Something happened in Holland to change this

154. LICHTENAUER, GESCHIEDENIS, supra note 37, at 118 (quoting the poet Bredero):

En oft schoon so gheviel, dat hij quam te fallieren;

En loopt hij om een Ces, 't is weer een man met eeren.

155. For an important Dutch text treating the problem as one primarily of opposing Christian and Roman traditions, see JOHANNES ClOPPENBURGH, CHRISTELIJCKE ONDERWIJSINGE VAN WOECKER/ INTERESSEN/ COOP VAN RENTEN/ ENDE ALLERLEYE WINSTE VAN GELT MET GELT (Amsterdam, Themis Jacobsz. 1637). The tale here is not solely a Dutch one, however, since large-scale rethinking of the usury problem preceded the Dutch seventeenth century. See, e.g., JOHN T. NOONAN, JR., THE SCHOLASTIC ANALYSIS OF USURY 365-73 (1957). 
pattern of resistance. But that something cannot be explained just by reference to the presence of Roman law, which was present everywhere; the Dutch must have been driven to behave in "commercial" ways by forces other than their familiarity with Roman law. ${ }^{156}$ All that we can really say is that DutchRoman law eased the way for the Dutch as they surrendered to the impulse to behave in "commercial" ways; all that we can really say is that Roman law provided authority for commercial behavior whose ultimate springs must lie elsewhere.

But to say that Roman law provided authority is by no means to say that it had no importance. It is only to say that our moral history of early-modern law must be different from the moral history written by our prewar forebears. The classic prewar scholars too often wrote as though Roman law had done more than provide authority. The classic prewar scholars too often wrote as though the spread of Roman law had somehow changed the deep, unconscious structure of values in European societies-as though the appearance of Roman law in some region of Europe had transformed everyday life, undoing all the silent "unreflective life-traditions" of socio-moral custom, inducing Europeans to act and perceive in a Roman way. ${ }^{157}$ Of course that is not the case. Maybe there is some quasi-Weberian argument by which we might believe that the spread of Roman law blew an ill wind of "rationalism." But it is surely not the case, on any argument, that the spread of Roman law caused Europeans to become "acquisitive." All human beings have acquisitive impulses; they need not be exposed to Roman law to develop them.

But human beings-particularly premodern ones-do not casually give in to all their impulses. They have doubts; they worry about what their neighbors may think; they worry about the sorts of shame (and worse) to which their neighbors may subject them; they hunt for authority, reasons, justifications. And people who hunt for authority and reasons are not people who live out dumb customary lives in the silent realm of the "unreflective." They are people who live thoroughly reflective, and sometimes loudly argued, lives, in the realm of moral choice. Early-modern merchants did not simply submit to "unreflective life-traditions"; they chose to submit—or not to submit;

156. This Article is not the place to develop any grand theories of the ultimate causes of the rise of Dutch commerce. I would simply like to emphasize that my analysis, far from arguing that Roman law "caused" the rise of commerce, inevitably assumes that some other, larger explanation for the commercial revolution is necessary. I should also note in particular that my analysis leaves open some large and important questions about market structure and credit practices. The shift from regulation of price to regulation of quality, see supra text accompanying notes 83-92, undoubtedly reflects in part the development of thicker markets, with participation by merchants who were specialists in their goods. Compare the description of the grain bourse supra note 79 and accompanying text. The development of the bankruptcy practices I trace, see supra text accompanying notes $135-48$, may also assume important larger shifts in Dutch credit markets. I do not discuss these issues, not because they are not of importance, but because it is proper to leave them to one side in an Article whose narrow topic is the moral impact of Roman law.

157. I model the phrase in quotation marks from the famous discussion of WIEACKER, supra note 31, at 131 . 
they made moral choices. Roman law provided justifications for some of their choices, and justifications with a magnificent antique lineage.

The slim, but speaking, body of evidence I have presented suggests how much that must have mattered to many merchants: to bankrupts like (presumably) Sicharnius, who owed their inner rehabilitation to the great Emperor Augustus, and who must have felt some bit of inner peace every time they saw one of the portrait busts of Augustus that decorated so much of baroque Europe; and to Dutch merchants driving hard bargains, who (unlike their English or Spanish competitors) carried handbooks that told them nothing about dangers to their soul, merely telling them what the shining name of Roman tradition permitted them to do. For such merchants, Roman law was not just a fund of clever juristic inventions; it was a source of indispensable moral authority. Leaving behind the restrictions of Christian society was no easy matter. It counted for much that there was a great Roman tradition that eased the inner fears of small men and allowed them to engage with freer minds in commerce; and for that reason, the rise of modern commercial society had a link with the recovery of certain pagan values. ${ }^{158}$

That brings me to a second point. The moral drama we see in these Dutch sources was about the recovery of certain pagan values; and this, too, is something that the classic prewar tradition failed, with some odd partial exceptions, ${ }^{159}$ to grasp. Prewar authors were not entirely wrong in declaring that Roman law embodied "unbrotherly" values. When a seminal nineteenth-century author declared that Germanic law embodied a principle of "brotherhood ... and moral duty," whereas Roman law treated all persons as "strangers to each other," he was speaking of a kind of truth; ${ }^{160}$ when German scholars of the Nazi era portrayed the Roman rules on overreaching as representing some kind of moral danger to traditional society, even they were brushing up against the borders of an important topic. ${ }^{161}$ But these German authors were wrong to identify Germanic law as the "brotherly" body of law. The moral alternative to Roman law was not Germanic village tradition, though in some ways it may have been village tradition; it was, first and foremost, Christian tradition. The critical error of the prewar scholarly tradition is not that it completely mischaracterized an underlying conflict in European legal history. The critical error is that the prewar tradition, deeply

158. I should emphasize that I do not mean to claim that commercial values of the kind whose rise I trace here were necessarily to be found in the world of antiquity; I mean only that they were to be found in the texts of Roman law as known in later European centuries. The practice of commerce in antiquity may well have varied from anything to be found in the Roman legal texts. To what extent practice and learned opinion were at odds in antiquity is a problem I must of course leave to the side in this Article.

159. The greatest odd partial exception is of course Gierke, who was well aware of the Christian roots of much of what he discussed. See, for example, the texts translated in OTTO GIERKE, AssociaTIONS AND THE LAW: THE Classical AND EARLY Christian STAGES (G. Heiman ed. \& trans., 1977).

160. SCHMIDT, supra note 21 , at 49,60 .

161. For the Nazi-era literature, see Wacke, supra note 63 , at 186-88; for the fallaciousness of traditional German claims about the character of Germanic law, see id. at 202. 
nationalistic as it was, characterized the conflict as one between Roman and "Germanic" traditions;, ${ }^{162}$ when in point of fact the conflict in question was much more one between Roman and Christian traditions. ${ }^{163}$ The tale of Western commercial law, at least as told by my evidence here, is not a tale in which local, communal traditions were overwhelmed by "foreign," Roman influence. The tale of Western commercial law is much more one in which merchants, who inevitably judged themselves not as citizens of some Germanic village, but as inhabitants of Christendom, slowly shook themselves free from Christian restrictions, citing, as they went, the moral authority of ancient Rome. ${ }^{164}$

In less dramatic ways, the same point can be made, moreover, about the moralizing social theory that we have inherited from Tönnies (as perhaps from

162. Compare the remarkable conclusions of Josef Kohler with regard to Dutch law, see KOHLER, supra note 38, at 247 (describing Dutch commerce as embodying "pure Germanic" values). Great scholar though he was, Kohler remained nationalistically blind to the Roman law in the Dutch sources-even though he was perfectly able, with regard to individual institutions, to see their roots in the medieval Roman tradition. See, e.g., $i d$. at 250-51, 255. See especially Kohler's bizarre nationalistic conclusions, $i d$. at $250-51$, recommending a deeper study of medieval Roman law, on the grounds that it was the accomplishment of the later medieval Roman lawyers to "preserve Germanic law." For this nationalistic tendency more broadly, see FEENSTRA, supra note 98, at 7-8.

163. Compare the wise remarks of Peter Landau in Peter Landau, Der Einfluß des kanonischen Reclits auf die europäische Rechtskultur, in EUROPÄISCHE RECHTS- UND VERFASSUNGSGESCHICHTE: ERGEBNISSE UND PERSPEKTIVEN DER FORSCHUNG 39 (R. Schulze ed., 1991), lamenting the dominance of a nineteenthcentury conception of history that reduced legal developments to a conflict between German and Roman law.

I should emphasize that in characterizing the conflict as predominantly one between Roman and Christian traditions, I do not mean to deny the existence of forms of an early nationalism in authors like Grotius, whose Inleiding was of course intended to speak to a Dutch audience, or even Udemans, who cared in his own way, too, about the "Fatherland." See supra notes 107, 46. I mean only to make the obvious point that neither author saw any conflict between love of the Fatherland and acceptance of Roman law; and that the conflicts over commercial morality that left their mark on both authors are best understood as conflicts between, in the first place, Christianity and aspects of the classical tradition.

I should also emphasize that I do not mean, by invoking the importance of Christianity, to deny that there were, in some sense, "popular" or secular traditions at work; as we have seen, the Christian and the secular were deeply interwoven. I mean only to say that if you pressed an early-modern European to explain what it was that justified "popular" traditions, you could expect, ultimately, to be told that those traditions were the traditions of a Christian people. Cf. Bergfeld, supra note 101, at 147 (medieval and early-modern persons "lived simultaneously in a sacred and a secular realm," with further discussion of the difficulty in fully distinguishing secular from religious law).

164. One other interpretive possibility deserves some attention. It is tempting to attribute the developments I trace here, in an indirect way, to the impact of the Reformation. In particular, it is tempting to attribute them to the typically Protestant decline of confession in Holland, linked with the greater circulation of moral and legal teachings in the vernacular. In Catholic Europe, we might argue, the hallowed doctrines of Roman law and Christian theology were communicated in sophisticated form to the priesthood, and passed on from the priesthood to the laity in confession. In Holland, by contrast, those doctrines were circulated directly to the lay community, in the form of the sort of vernacular texts I have used here. Dutch Christians, we might thus say, were offered the teachings of Roman law and Christian morality directly, with the typically Protestant injunction that they judge for themselves; and this, we might argue, explained the wider acceptance of Roman law that my evidence seems to show. For an observation supporting something like this line of argument, see VINER, supra note 12, at 49 (observing that sophisticated economic teachings, which were presented to the Catholic world only in Latin, "maintained a secluded existence in the seminaries and the confessional"). The same was, of course, not the case in Holland.

The prime difficulty, however, with this line of argument, is that it should hold true not only of Holland, but of much of the rest of Protestant Europe. For that reason, I have resisted developing it in the text. Nevertheless, I do want to note its attractiveness as an interpretive hypothesis. 
Marx). Tönnies was not a nationalist; he "purified" (to use his word ${ }^{165}$ ) the nationalistic idea of a Roman-German conflict into the sociological idea of a primitive-modern conflict. But even Tönnies's "purified" sociology was still marked by what marked his nationalistic sources. There is indeed a conflict between "community" and "society" to be detected in the Dutch literature. But that conflict is not obviously one between the primitive, folk-based way of life and the modern, urban way of life. It is at least as much a conflict that grew out of the slow breakdown of Christian values. "Community," as it appears in the sources I have discussed here, has little to do with village values, and much to do with the teachings of St. Paul. This suggests that we should be wary of extending Tönnies's sociology of "community" beyond its natural home: the European world in the loosening grip of Christianity.

Having argued these large points about European socio-legal development, I would like to close with a few small points about what legal historians can profitably study: with something about the importance of the literature of lay practice, something about the importance of the history of commercial law, and, especially, something about the importance of the history of commercial morals.

First, it is indispensable that legal historians read, and reflect upon, the literature that lay folk consumed. The technical writings of the great Dutch scholars have monopolized the attention of our best European legal historians. Unsurprisingly so: Those technical writings are of cardinal importance for understanding the development of European legal doctrine. Yet it was merchants, not jurists, who made the great commercial revolutions, in Holland and elsewhere; and our legal histories are fundamentally incomplete if they do not attempt to conjure up what the law meant to business folk, and to similar crude consumers of the law. Law, in the last analysis, does a simple and brute thing: It tells people what they are allowed to do. Legal historians must be ready to work through the simple and brute calculations of "can I" and "must I" that laypeople work through. That does not mean that the work of the great learned Dutch jurists is irrelevant to my story. The learned jurists took an interest in everyday problems, at least to some extent. ${ }^{166}$ And the ideas of the

165. As in the full title of his work, Gemeinschaft und Gesellschaft. Grundbegriffe der reinen Soziologie ("Community and Society: Basic Concepts of Pure Sociology"), see TÖNNIES, supra note 23. In Tönnies's search for "basic concepts" we should arguably see, again, the influence of an aspect of German legal thought: here, the influence of Begriffsjurisprudenz, of the "Jurisprudence of Concepts." For a fine English-language introduction to the Jurisprudence of Concepts, see Matthias Reimann, Nineteenth Century German Legal Science, 31 B.C. L. REv. 837 (1990).

166. For the engagement of the learned jurists with practical problems, see Zimmermann, supra note 37, at 1712-13. For the tendency of some of their thinking to dovetail with developments in practice, see supra text accompanying note 105. The jurists could, however, quite comfortably be interested in practice while maintaining a hostility to commercial values. On that hostility, see the remarks of LICHTENAUER, GESCHIEDENIS, supra note 37, at 26-29, 56-59, 71; and discussion supra note 144 . The existence of such at least intermittent hostility means that we must be cautious in our use of the learned literature, as I hope Professor Zimmermann would agree. 
learned jurists filtered into the literature of practice, if sometimes only slowly. Most importantly, the very presence of eminent scholars in Holland symbolized, and reinforced, the general cultural cachet of Roman law that is my topic in this Article. All of this means that we must know the work of the learned jurists - but we must read that work, at least some of the time, through lay eyes. We must read the rules the way laypeople read them: dreading penalties, skirting traps, eager for justifications and advantages.

Second, legal historians must remember something that they too often used to forget: The history of commercial law matters. The nineteenth-century tradition, for all its obsession with the rise of commercial society, often took oddly little interest in the workings of commercial transactions. The great problem, as nineteenth-century scholars often conceived it, was always a problem of something other than the actual doing of commercial deals. It was a problem of property law; or it was a problem of the rise of rational forms. Yet the influence of Roman law shows most clearly in commercial matters-which surely should have occupied the bulk of our attention from the beginning. The great question of the origins of commercial society is not, in the first place, the question of how shifts in property law gave rise to acquisitive values; nor is it, in the first place, the strange phenomenological question of how Europeans came to view the world more "rationally." The first great question is the question of how European merchants overcame the queasy conviction that markets were focuses of evil, and that it was dangerous to the soul to participate in ordinary commercial transactions. And the great importance of Roman law was that it helped them overcome that conviction. Wise medievalists have understood this for some time-even if they have been so unwise as to focus their attention exclusively on the Middle Ages.

If the history of commercial law matters, so too, finally, does the history of commercial morality. Historians of commercial law have too long occupied themselves with the history of legal technique, and particularly with the prehistory of current legal technique; their interest has always been in the rise of the doctrines that we know now. Yet the most important history may be the history, not of the rise of the sophisticated doctrines we know, but of the decline of the primitive beliefs we have forgotten. Commercial society only arose when beliefs that are strange to us collapsed-beliefs in matters like just price and the shamefulness of insolvency. We retain only the barest memory of those beliefs, in the form of things like our anxiety over insider trading, or our indignation at the idea of the "stigma" of bankruptcy. Yet we must cultivate those fading memories and recover some sense of the moral fears of our ancestors. This will require us to overcome some deep and understandable reluctance; for legal historians remember well the time, in the terrible German catastrophe sixty years ago, when the discipline became all too caught up in 
the politics of premodern moral fears. But we must be willing to think again about those moral fears, even as we keep our distance from them. If we do not, we will never really understand the making of commercial society. 
HeinOnline -- 105 Yale L.J. 1890 1995-1996 